\title{
GEOLOGY OF OSCEOLA AND DICKINSON
}

\section{COUNTIES.}

BY

T."H. MACBRIDE. 


\title{
GEOLOGY OF OSCEOLA AND DICKINSON COUNTIES.
}

\author{
BY T. H MACBRIDE.
}

\section{CONTENTS.}

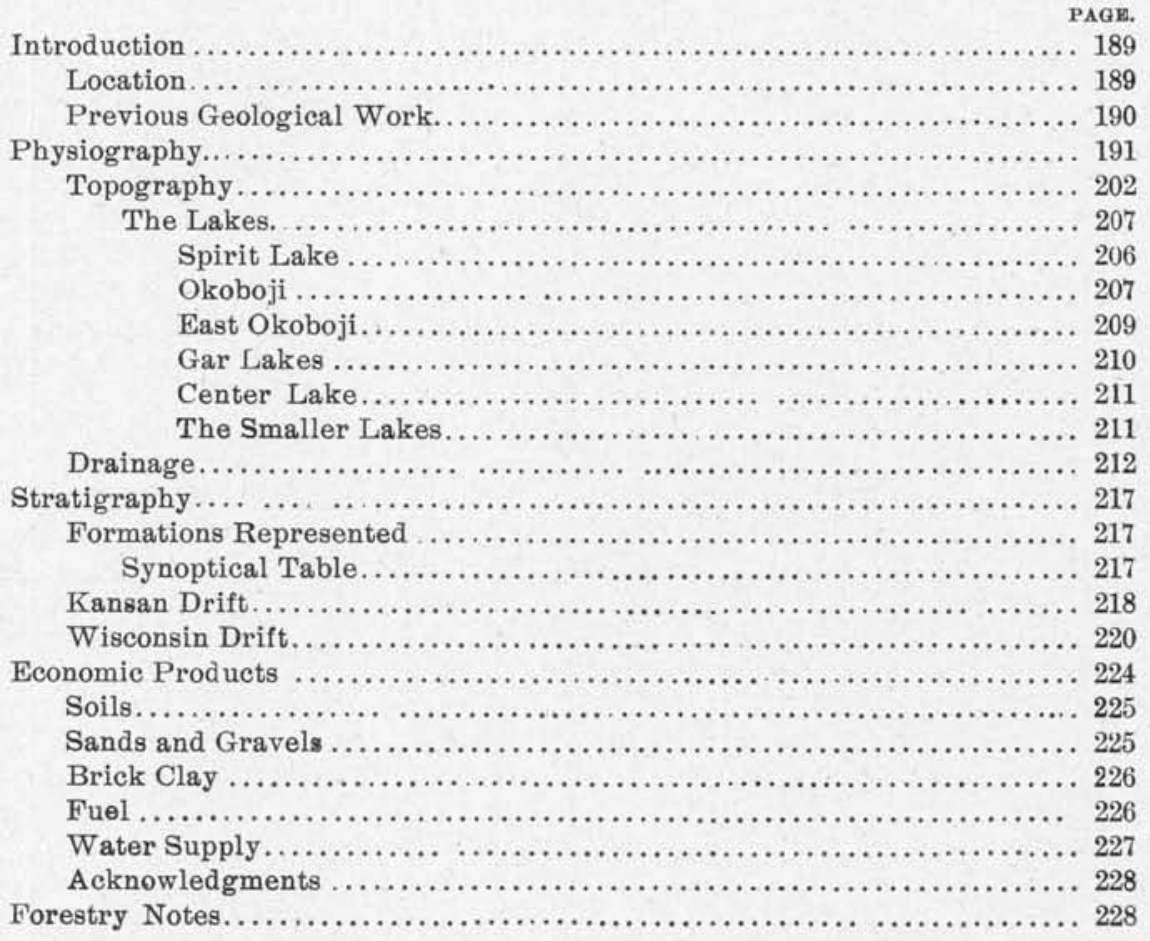





\section{INTRODUCTORY.}

LOCATION.

The two counties, Osceola and Dickinson, which form the subject of the present dissertation, lie in the extreme northwestern region of Iowa, Minnesota bounds them on the north, and on the west but a single county, Lyon, separates Osceola from the Sioux river -in this latitude the western frontier of the state. By the authorities of the Survey these two counties have been grouped together because it was supposed that here the several problems to be investigated, topographic, geologic, biologic, would present eommon features, so that the proper discussion of one county would almost necessarily involve research within the limits of the other. This view of the situation, as will appear has been only in a measure justified. Dickinson county presents many features which ally it more closely with the region east and south, while Osceola and Lyon county ought rather to be united. But, in fact, no two of these counties, nor indeed any one, ought to studied wholly as a disconnected fragment. The whole northwestern prairie is a unit and although details must still be picked up, probably county by county, still any report, as the present, ought to be reckoned largely provisional, subject to such subsequent revision as will no doubt be possible when the future student comes to contemplate at once the entire section of which our two counties form but a narrow segregated part. Dickinson county is pre-eminently the county of lakes and well isolated kames; Osceola is an elevated plateau, in many places nearly level, in others affected by long southward winding, trough-like valleys, offering a system of constructional 
drainage belonging to the original make-up of the country, and not resultant from the erosion produced by present streams, lost within such ample limits. In both counties the drainage is imperfect, peculiar, pre-determined in an unusual way, and therefore well worthy of our study. Nor is the topography less interesting because of but few types; the very plains and valleys, the kames and hills, are all the more wonderful because in origin withdrawn from the operation of ordinary causes, and requiring for explanation the introduction of external agencies which have to do with planetary, not to say cosmic, phenomena. The lakes of Dickinson county are almost the only natural fextures of the kind within the limits of the state. Their wonderful beauty as well as their unique position would seem to warrant special consideration, and we attempt a fuller description than has hitherto been given. The flora of the region likewise possesses its interesting features and is discussed at some length in the last chapter under the heading, Forestry Notes.

PREVIOUS GEOLOGICAL WORK.

The earliest mention we have been able to trace of this interesting region is found in the notes and journal of the celebrated Lewis and Clark expedition, 1803-6.* The redoubtable Clark in his notes relates how " the Ceuoux river passes through the lake Despree." There can be no doubt about that reference. But in the formal Journal under date of August 8,1804 , we find the interpreter, Durion, describing in connection with the same Sioux river "a large lake nearly sixty miles in circumference, divided by rocks which approach very closely, * * * it contains many islands and is known by the name of Lac d'Esprit."

Nicollet certainly saw this region of the state in 1838-9, perhaps in company with Fremont, and his report† not only names Minnewaukon or Spirit Lake, but accurately describes

\footnotetext{
*A History of the Lewis and Clark Expeditions, Ellott Coues, Vol, 1, pp 69.70.

+Report Intended to fllustrate a map of the Hydrographical Basin of the upper Mississippi river, $m$ ide by J. N. Nicollet, publish $3 d$ as House Document No. 52, Second Session, Twenty-elghth Congress, Janu $4 r y$ 11, 1845.
} 
it and for the first time gives it a place on the map of the world.* Considering the circumstances under which he worked Nicollet's map is wonderful, and his descriptions of the Coteau des Prairies are remarkably graphic.

Ten years after Nicollet, the famous David Dale Owen seems to have visited northwestern Iowa. His report $t_{+}$leaves it uncertain whether he personally investigated the lake country; but he includes it in his description of the Coteau and of the "knobby drift."

These men were pioneers in geologic science, and in the present sketch there will be occasion once and again to refer to them and to their work. Nicollet's map and Owen's report are classic beginnings which later students may seek to emulate but must not hope too easily to surpass.

The scope of Hall's effort in the work he was permitted to accomplish for Iowa did not include the northwestern prairies, then, because destitute of mineral wealth, held in less esteem. Dr. White, however, studied the prairie counties very carefully, made the first attempt to explain the lakes of Dickinson county, and has described and even figured the topography of Lake Okoboji.§

\section{PHYSIOGRAPHY.}

TOPOGRAPHY.

The topography of the region before us, for a prairie district, is remarkably varied; we have high mountain-like hills and ridges with corresponding but exceedingly irregular and non-continuous depressions; we have wide expanded lakes but no affluent, and sometimes no regular, effluent streams; we have long, winding, insignificant rivers, moving anon sluggishly in valleys extremely wide, and again similar currents

\footnotetext{
*Lewis constructed a map "complled from the authority of the best fnformed travelers," copled in 1806 by Nicholas King, which was submitted to Jefferson, as it appears, with the Lewis and Olark Report. But this map was never published until 1887 . On this map the "L. Dispre" appears located with a falr degree of accuracy. See Hist. of the Lewis \& Clark Expeditions, E. Coues, Vol. 1, p. 221.

\$Geological Survey of.WIsconsin, Iowa and Minnesota; LIppIncott and Grambo, Phlladelphla, 1852 .

sReport on the Geologlcal Survey of Iowa, by Charles A. White, M. D., Vol. I, pp. 70-73, and Vol. II, pp. 219-23, and 226-29.
} 
hemmed in by preeipitous hills through which ehance has determined a tortuous and difficult escape; we have wide gravel-plains eut by the channels of recent surface-drainage, and sometimes broad, level meadows, dotted with pools, marshes and lakelets with no drainage at all. So peculiar is

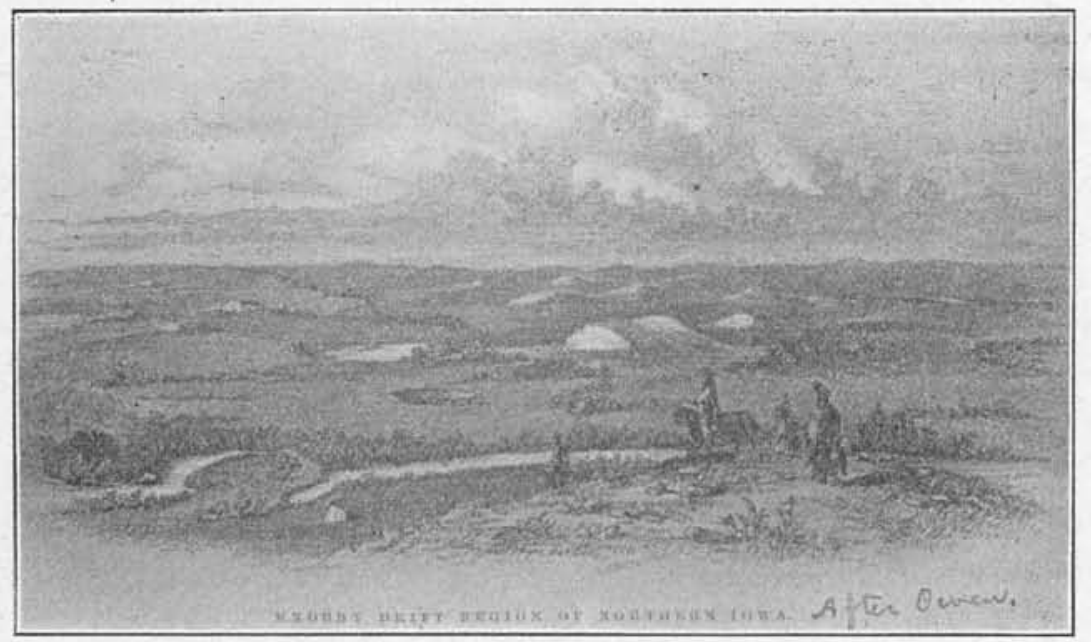

FiG. 16. Knobby drift region of northern Iowa. After Owen.

the hill-country here described that it has attracted the wondering attention of every visitor from Nicollet to the latest summer traveler. Just such hills and valleys are seen scarcely anywhere else in Iowa, although the region around Clear lake already described in these reports furnishes in some respects a parallel. * But in Cerro Gordo county the region affected would seem less extensive although no doubt its ridges and hills constitute a similar and correspondent geologic boundary. Owen was so much impressed with the peculiar conformation of northern Iowa that he figured these singular hills. He called the formation the "knobby drift" and his sketch is so good that we have here reproduced it as affording a better idea of the topography in question than any photograph could possibly have done. $\dagger$ Owen's figure

* Cr. In the present series Iowa Geological Survey, Vol. VII. pp. 132-4.

+ Owen, Geology of Wisconsin, Minnesota, and Iowa, p. 104.

19 G Rep 
illustrates, perhaps, some landscape in the Clear lake country, or, as he denominates it, " the Knobby Drift Region, sources of the Upper Iowa," but his description as well is very graphic and carries the knobby drift at least very near the area now under investigation. He says: * "After passing latitude $42^{\circ}$ $30^{\prime}$, and approaching the southern confines of the Coteau des Prairies, a desolate barren, knobby country commences, where the higher grounds are covered with gravel and erratic masses, supporting a scanty vegetation, while the valleys are either wet and marshy, or filled with numerous pools, ponds, and lakes, the borders of which are inhabited by flocks of sand-hill cranes, which fill the air with their doleful cries, and where the eye may often wander in every direction toward the horizon, without discovering even a faint outline of distant timber.

"This description of country prevails for about threequarters of a degree of latitude, and between three and four degrees of longitude, embracing the water-shed where the northern branches of the Red Cedar and Iowa, and the eastern branches of the Des Moines, take their rise."

The phrase " bêtween three and four degrees of longitude," if we begin at the $93 \mathrm{~d}$ meridian, which is east of the point sketched, will make Owen's description cover all the northern tier of counties as far west as meridian 96, west of our limits. However this may be, there is no question as to the presence of Owen's knobby drift in the territory we now study. By reference to the accompanying map it will be seen that this peculiar topography covers nearly, or quite one-half of our entire area. The southern line of demarkation is a tortuous one. Beginning east of Swan lake it extends west just north of the town of Superior, thence south and west to about the center of Milford township, then northwest, turning at a point north of Milford, west and a little south until it passes Pillsbury lake, thence northwest toward Harris, in Osceola 
county, on west to include the Ocheyedan country, then northwest, vanishing at last as it passes the diminished kames of Wilson township. It will of course be noticed that this line includes all the larger lakes; small wonder that the curious conjunction of lakes and prairie-hills has long been the subject of popular remark. It must not be inferred that all the region included by the boundary just sketched is entirely given over to precipitous hills; within these limits are many areas comparatively level, in some cases almost perfectly so, wide meadows with lakelets and marshes, as well as many beautiful farms; but within the limits described and north to the state line, hills and mounds mark the topography as nothing else. Moreover the hills are somewhat associated in groups, gathered about centers where some especially lofty point seems to dominate all the rest. Thus we have the group north of Swan lake, for the most part a series of nearly parallel ridges running east and west. These ridges are much broken up of course, and nowhere continuous for any great distance, but their general trend is as described, and from their summits the most magnificent vistas lie revealed, especially northward where the villages of Minnesota dot a level prairie. Another group lies east of East Okoboji lake and centers near Prairie lake in a point 150 or perhaps 160 feet above the water level. Another group of hills of the most irregular character lies between Spirit lake and Okoboji and eulminates in a high peak in the northeast corner of the Ne. $\frac{1}{4}$ of Sec. 1, in Lakeville township.

The hills about Diamond lake, those northwest of Silver lake, those of Fairview township in Osceola county, simply defy classification or description; they pitch toward every point of the compass, they are of every height and shape, they rise by gradual ascent and fall off by precipices so steep that the most venturesome animal would scarcely attempt descent; they enclose anon high tablelands, anon wide low valleys that open nowhere; they carry lakes on their summits and undrained marshes at their feet; theirgentler slopes are beautiful prairies 
easily amenable to the plough, their crowns are often beds of gravel capped with bowlders and reefs of driven sand.

The most remarkable of all these hills, a beautiful object in itself, and by far the most elegant illustration of its type, is the long time famous Ocheyedan* mound (Fig. 17). This is a

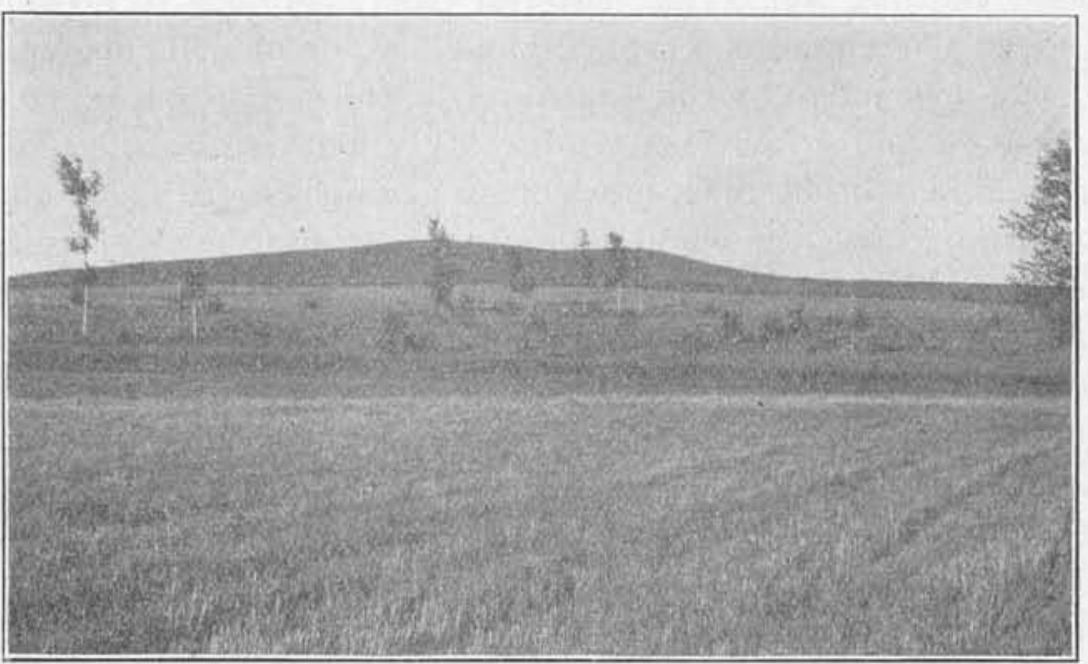

Fig. 17. The Ocheyedan mound, seen from the southwest.

prairie mountain, a precipitous knob or peak, rising at last abruptly from the general surrounding level. It is situate in the Sw. $\frac{1}{4}$ of the Sw. $\frac{1}{4}$ of Sec. 12 in Tp. 99, R. XL, W. on the east bank of the Ocheyedan valley, and about one mile southeast of Ocheyedan town. One hundred and seventy feet above the valley flood-plain, and at least twenty feet higher than any surrounding land, it has long been a landmark and is visible at their homes to hundreds of the citizens of Osceola county. The height above sea-level, as estimated from data furnished by railway surveys, is not far from 1,670 feet, one of the highest points in Iowa, its only rival the summit of the moraine in Wilson township northwest of Allendorf, which has probably about the same elevation.

*Pronounced O-chee-dan; Nicollet has this to say: "Otcheyedan-a namederivedifrom a small hlll, the literal meaning of which is 'the spot whare they cry'; alluding to the custom of the Indians to repatr to elevated situations to weep over thelr dead relatives." - Nicollet, Report of the Upper Mississippi River, etc., p. 27. 
tion. The general trend of the mound is northwest-southeast, extended diagonally across forty acres. The extreme length is accordingly about one-third of a mile. The northwest face and the sides are very precipitous; the sides especially so, marvelously so when we reflect that we have no rocky core, nothing but loose material easily subject to erosion. Indeed the mound is a typical kame," a pile of drift made up, if one may judge by the exposure on the northeastern face, of sands and gravel-beds alternately but irregularly laid, cemented anon by lime, more often by deposits of accumulating iron. Over the whole mound lie scattered bowlders some of large size, where granite, porphyry, Sioux quartzite and limestone are strangely intermingled. The width of the summit at its narrowest point is no more than twenty or thirty feet, but the surface slopes off so gently to the southeast that a wagon-road has been constructed from that direction, and it is possible thus to make the ascent with ease. The view from the mound-top is well worth the effort to obtain it; to the south and west the valley of Ocheyedan, wide and flat limited by the broad morainic ridge on which stands Allendorf and, farther west, the town of Sibley; to the northwest Ocheyedan town with low hills like a tumbled sea lost in the northern plain; to the northeast the same low swelling hills and hummocks to Harris and Lake Park, and so round again to the farthest southeastern limit, where once more the horizon melts to the unbroken level of the prairie. Two similar mounds lie immediately north of this one, and a third in the northwest quarter of section 4; one is immediately west of Rush lake; but these, though large and high, are unnoticed in presence of the "hill of mourning".

But the remaining half of the region we are studying possesses also topographical characteristics of peculiar interest. The ridge just mentioned, which extends diagonally south. west almost across Osceola county is, to one approaching

\footnotetext{
*A ridge or hill. Compare comb, that is, a ridge as of a house. The word seems to be Scotch and was first used by Scottish geotogists to designate a mound or hill of glacial origin.
} 
from the east, a very striking topographic feature. Through the greater part of its extent it presents toward the northeast an abrupt, almost precipitous face, which, in the latitude of Ocheyedan mound, is 150 feet above the valley lying before it. Two miles west of Ocheyedan station the bluff faces directly north, and along this face the railway climbs for the distance of about a mile on the way to Allendorf. After reaching the crest of the moraine the ascent still continues, and Allendorf station is sixty-six feet higher than Ocheyedan station, and so probably within thirty feet of the summit of Ocheyedan mound. As the surface continues to rise from Allendorf north and west, there seems little doubt that there are several points in Wilson township where the barometer will mark an altitude almost, if not quite, as high as that of the famous hillock. These high points are by no means necessarily hills, nor possibly at all recogaizable to one passing over the county. One of them, at least, is a marsh of considerable extent and forms the source of the Little Ocheyedan creek. Others are broad fields sloping gently in all directions. At most the various points of the highland here described vary but a few feet in comparison with one another, and none of them fall short of the mound by probably more than fifteen or twenty feet.*

At any rate the ridge in question forms a water-shed, distributing in all directions save north. Eastward the waters join the Little Sioux, westward the Rock river and south the Floyd. To the passing observer the country seems perfectly flat, except as disturbed here and there by recent erosion or as marked by an oceasional diminished kame; but the land really slopes everywhere gently to the west or southwest. The moraine is from six to ten miles in width and blends to the southwest into an entirely different topography, where the level is fully a hundred feet lower.

\footnotetext{
*It would be faterestlag once for all to settle this questlon of altitude, but the Survey was not in possession of the requisite Instruments. From such data as are at hand the present writer concludes that the highest polnt in Osceola county, and this means the highest polnt In Iowa, is near the center of Wilson township, and has an altitude not far from 1,670 feet. 19 G Rep
} 
The land formation of the southwestern part of Osceola county is another region which, on account of topographic interest, deserves mention here. Beginning a few miles south of Sibley the erosion features of Otter creek valley, and indeed of nearly the whole of Gilman township, are strikingly unlike anything else of the kind seen in our present territory. In short the topography is erosional, not constructional, a fact which becomes more and more patent as one follows to the southwest the road from Ashton to Sheldon. The valleys are not always wider nor deeper, but they form a more plainly developed system, with tributaries again and again subdivided. In fact the drainage of the Ashton region is better than is shown anywhere else in either Osceola or Dickinson county.

But there is a third topographic peculiarity of this section which warrants reference and description. In various places on hillsides, and especially by the margins of the larger streams, there are peculiar deposits of gravel which now and then widen out into considerable plains. The most remarkable of these is seen in Dickinson county, immediately south and west of the town of Milford. Here we have a sandy, gravelly prairie. some two or three miles in width and reaching the southern boundaries of the county, following in general the course of the Little Sioux river, almost level save as affected by local erosion, without kettle-holes, and entirely destitute of those features which mark the level prairies in other parts of the county. As we shall see farther on, the gravel prairies owe their existence to conditions altogether unlike those which have operated elsewhere to create the level portions of this particular part of Iowa. Through this plain of gravel and sand the Sioux, or rather the "outlet," as the discharge from the lakes is called, has cut a deep but not wide channel. The mill-pond of old Milford occupies part of this erosion channel, and the mill-pond of the Okoboji Mills forms a continuation of the same depression. Farther south and west after the entrance of the Little Sioux the erosion has left on the west side of the valley a remarkable terrace (Fig. 
3) which may be traced to near the middle of section 22 , in Okoboji township. Farther down in section 33, just before the river leaves the county, the bluffs of drift approach each other very nearly; are within perhaps a half a mile of each other. Here the terrace is best displayed on the west

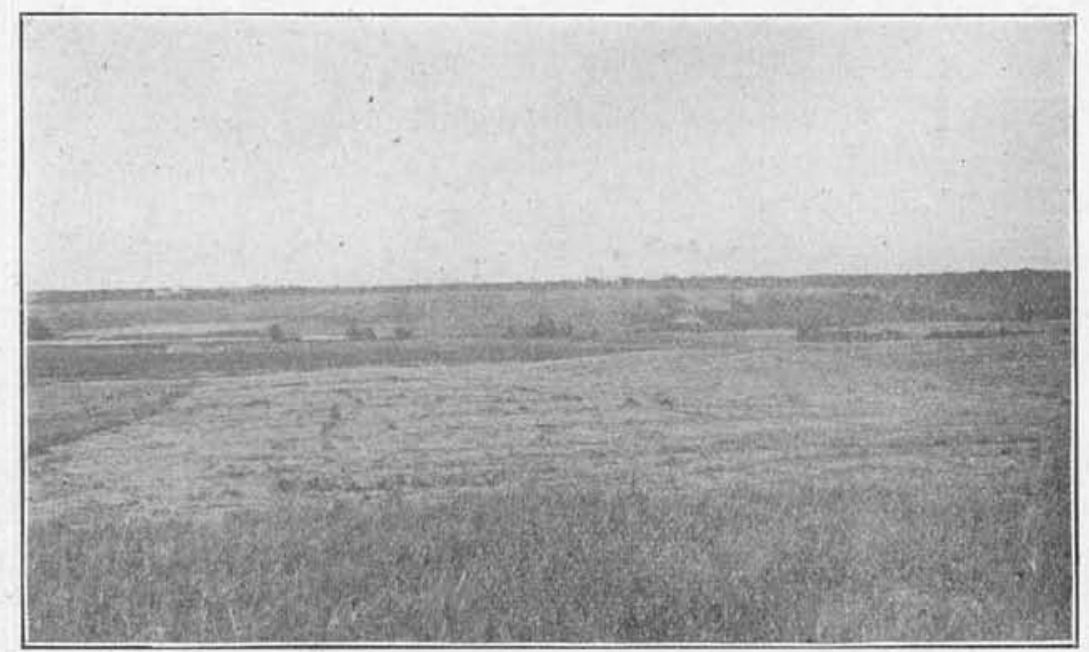

Fig. 18. Milford Terrace, seen from the east side of the Little Sloux.

side of the stream and is very marked, though narrow, a remarkable shelf, lifted at least fifty feet above the level of the present river.

Similar gravel trains or terraces are diseoverable along the lower portions of Muddy creek, of Otter creek, and the Ocheyedan. Sometimes the formation is represented by a trace only; at other times it forms a bank more or less distinctly noticeable,-generally attacked by the farmers as a gravel-pit. It is to be noted that these terraces and gravel plains lie almost entirely outside the margin of the hill-country above described: are nowhere represented, except the kames, by anything more than a bank or trace within it. The sandy shores of Spirit lake must, however, be referred to again later on. They do not belong to quite the same category 
as the stream terraces here described, although evidently made of the same materials.

The stream-valleys in these counties are in every way peculiar. Hardly one of them shows a history of simple continuous erosion. The gravel deposits just described indicate successive chapters in the story. The valleys have been eroded, filled up and eroded again. This is indicated plainly enough by the situation south of the hills. In the hill-country proper the valley is sometimes erosional, sometimes constructional. Let anyone interested compare, for instance, the two forks of the Little Sioux river, as these occur in the northern part of Dickinson county. The west fork is a tortuous steam, crossing meadows or winding among hills which it is still eroding, first on one side, then on the other; the east fork, especially in Diamond Lake township, lies chiefly in a wide valley which might easily have formed the basin of a great lake extending north and south. See particularly the view of the valley as seen from the northwest corner of section 32 in the township referred to. Or compare Dug-out creek, in Dickinson county, with Otter creek, south of Sibley, in Osceola county; the contrast could scarcely be greater.

The lakes, too, should be noticed in this connection. They lie in great depressions which are constructional; have no reference whatever to any drainage-system, at least of recent times. The long chain of lakes from Spirit lake south to the Little Sioux river, may have ever formed as now the channel of a southward moving stream, but the channel is not the creature of the stream; even the "outlet" owes to erosion but the later touches. The wide basin-like depression until lately used as the Milford mill-pond has suffered erosion on the western side but in its broader features seems to have been determined by other agencies. The surface of Lake Okoboji is more than forty feet below the Milford plain, while the surface of Minnewaukon or Spirit lake, although at present ten feet or more higher, is more than 100 feet below the highlands on either side of it from Superior almost to Lake Park. The 
finest view of the topography of the lakes just mentioned is obtained from points along the highway in sections 22 and 23 in Center Grove township. The site of the church in the Sw. $\frac{1}{4}$ of the Nw. $\frac{1}{4}$ of section 23 is 150 feet above the level of the water of East Okoboji lake (September, 1899).

It will be seen from all this that the topography of the country we study is not explained by reference to causes now at work in the locality. No stream, no floods of storm-water, ever cut a valley which has no outlet, or created hills of every size and height with undrained valleys on every side. In fact it is difficult at first sight to see how any force whose action is known to students could bring about just the effects we here behold. The only agency to which appeal is made is that of moving and melting ice. These phenomena are glacial. They fix for us by their very irregularity the limits of some ancient glacier's action, the borders of its ebb and flow. That the glacier was here we know by the abundant drift, to be further on discussed; that it rested here is certain, else had all this drift been spread abroad, every "valley exalted and every mountain and hill made low," and the whole country reduced to the marshy plain so widely characteristic of the counties to the south and east, over which the glacier is understood to have accomplished its perfect work. The conditions before us are, therefore, morainic and are explainable only as that fact is kept constantly in mind. The margin of the glacier is never uniform either in situation or direction.s It varies constantly, now extending, now retreating, often changing with each succeeding season. More than this, our problem is still further complicated in that our moraine is only quasi terminal; it is lateral or termino-lateral. It is probably ter minal with respect to the ice-movement of any particular locality but lateral in its relation to the progress of the glacier as a whole. In many places we have probably the resultant of both movements, the effect produced by various forces acting in different directions at the same time, with results not unlike those caused by eddies at the border of some majestic river. 
It must further be premised that the agencies in question were active in the same way over an area of very considerable extent, in which was found all needful room for the great diversity we have so far described. The Iowa glaciers were very wide and their moraines are proportionately broad. It need not therefore be a matter of surprise to find, as in the present case, morainic deposits spread over a width of nearly thirty miles. The entire hill-district above mentioned, in all its confused and tumultuous disorder, lies before us, the record of the lateral moraine of an ice-sheet once extending east and west from Osceola to Cerro Gordo eounty. In recent geologic literature the term Altamont has been applied to that particular part of any morainic deposit which marks the extreme limit of this glacier flow or thrust. In the case before us the wide ridge west of Ocheyedan river seems to be the Altamontane crest, marking the glacier's furthest western movement, a levee, a dike, behind which all subsequent recessions, cross movements, advances, eddies and retreats performed their marvelous work. The western limits of this ridge are difficult to define. The Little Ocheyedan drains its summit; beyond, the deposit gradually fades out of sight, so that it will require much closer investigation than has yet been given to define exactly where lies the ultimate boundary. In fact the ice itself seems to have thinned out at its very margin and to have carried with it a proportionately less amount of.drift. This was spread beyond the summit of the ridge in varying thickness, sometimes in patches, and finally fails entirely. To the northwest the ridge widens and is less conspicuous; at the southeast it is much narrower and we may hope that its limits southward may be easily determinable, once the topography of O'Brien county becomes a matter of investigation.

THE LAKES.

The lakes of our region lie almost all in Dickinson county. Not that Osceola is destitute of similar topographic features, 
but for some reason the peculiar conditions that resulted in lakes of size were developed farther east. Iowa lake in the northern part of Fairview township, extending northward into Minnesota, is the finest lake now seen in Osceola county. Rush lake, northeast of Ocheyedan, visible from the car win-

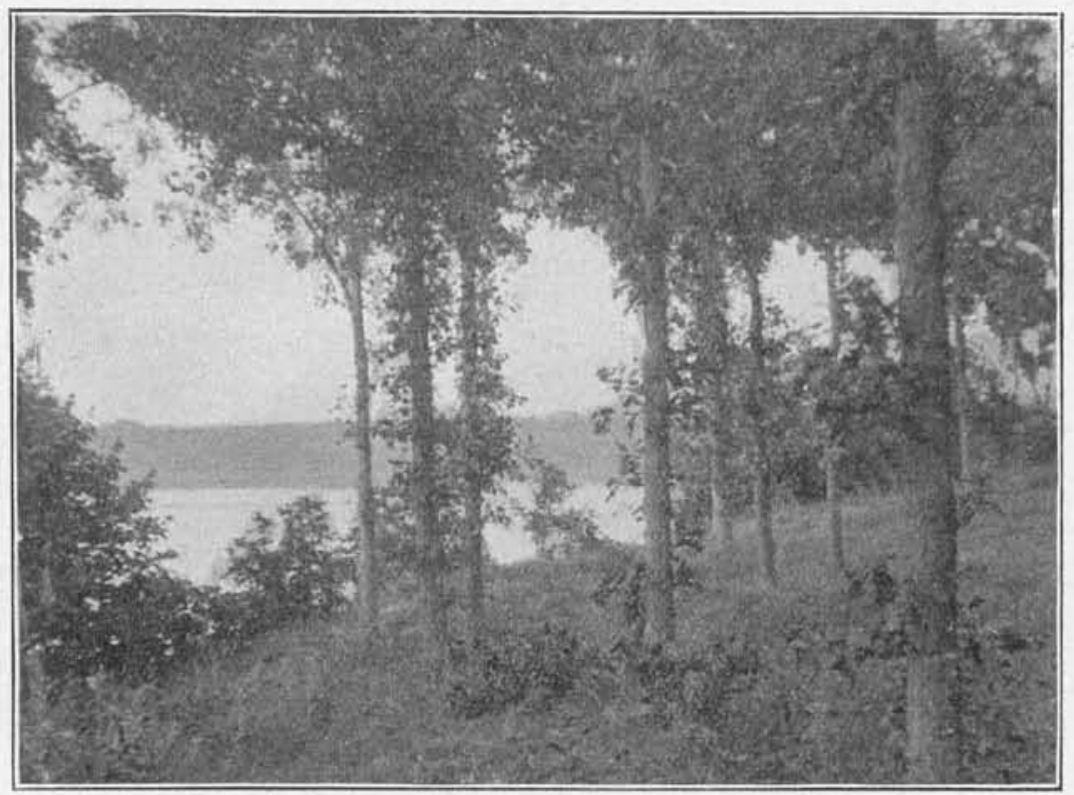

FrG. 19. A glimpse of East Okobojl seen through the ranks of young Bur oaks.

dows to travelers along the Burlington railway, is, as its name implies a great morass or marsh, covering altogether about a section of land. Similar swamps and lakes, but far smaller in extent, are not infrequent throughout all the morainic hill-country, especially north and east. Many of these hitherto marked on the map have been successfully drained and are now cornfields and meadows. But in Dickinson county the lakes are the features of the topography, many of them deep enough to promise permanency, and several so large as to have long attracted popular attention by their beautiful blue waters and the charming outlines of their shores. (Fig. 5.) Minnewaukon or Spirit lake, is as we have seen, historic, nay, is it not prehistoric? Even for the 
red man these beautiful gems of the prairie had name and fame. He hung them around with legends of his own and named them in his own poetic, mystic fashion. Okoboji, place of rest; Minnetonka, great water; Minnewaukon, lake of demons, lac d'esprits, were every one apparently familiar to all the tribes and nations of the Sioux, and were doubtless known by name at least to all the eighteenth-century trappers and voyageurs. Okoboji, evidently distinguished by the red man, was by white explorers generally reckoned part of Spirit lake, and is so entered on the earlier maps. The two bodies are in fact part of a remarkable system extending in chain-like fashion for twenty miles or more in Iowa and probably almost as far in Minnesota. Nevertheless, the greater lakes have now no natural connection with each other; they are in general quite unlike and have, in some details at least, a different geological history. In all cases the water level seems dependent entirely upon rainfall. The few springs discoverable are small and insignificant, while of affluent streams there are practically none; none at least that bring in perennial waters. The overflow of the Minnesota lakes, it is claimed, reaches our Spirit lake, and certain smaller lakes to the west and north are also on occasion tributary. But all the lakes, whether in Iowa or Minnesota, are subject to similar fortune. In rainy seasons full, they send their waters to the common outlet; in drier years there is no surplus and the outlet fails. In fact the lakes are each and all simply great pools left on the surface by the retreating glacier, marking points where the ice was somewhat thicker or the amount of detritus carried somewhat less abundant. They owe not their existence to erosion; no recent change of level has formed an outlet for their waters; such as they are, such were they when the latest geologic epoch closed. The present form and condition of the outlet would not suggest that the principal lakes, at least, have ever been much deeper than at present. The outlet valley is largely constructional and while there has been erosion, considerable in the vicinity of 
Milford, still erosion has not in time past much affected the level of the lakes, does not at the present day seem to affect them at all. Those familiar with the situation for the last four or five decades assert that Spirit lake had formerly a natural outlet southward. There is no sign of it at present. On the other hand the out-thrust of the ice from winter to winter has tended to form a species of dyke almost entirely around the lake, especially along its sandy beaches, and this alone would seem to have been sufficient to close up any connection, slight and shallow at best, between Spirit lake and the waters south of it. At any rate there is along the south shore of Spirit lake a pronounced terrace, which is natural and due to the causes mentioned. There are, however, evidences, chiefly afforded by terrace-construction, that the water level in the lake has been higher in days gone by than now, perhaps ten feet higher. In such event there would be an overflow southward. Probably the level of the lake has oscillated through the centuries. With a succession of dry seasons the water would become so reduced that out-flow would cease entirely. The sand pushed up in winter by the ice would then form a dam higher and higher and which at length only a very considerable rise in the waters of the lake could surmount. Then probably some exceptionally rainy season would wash out the obstacle and again reduce the level of the lake, making possible again the construction of the dyke. In the maintenance of the barrier vegetation very much assisted. To-day various aquatic plants hold the shallower parts of all the lakes in possession undisputed and greatly check the movements of their waters. In fact by reason of abundant vegetation many of the smaller lakes are now in danger of being completely filled. The plants, many of them rooted to the bottom, at once absolutely prevent erosion, and at the same time hold all solid matter coming in from whatever source from without. For this reason the general outlet of the system, the south end of the south Gar lake, is not 
deepening, but seems to be actually rising year by year. But it is time we should describe the lakes more in detail.

Minnewaukon or Spirit lake, the largest body of water in Iowa, occupies the greater part of the township of the same name. Its extreme length from north to south is a little more than four miles, in Iowa. The extreme width is about the same, but owing to irregularity of contour the area is not more than ten square miles, while the circumference is nearly sixteen. The depth of the lake is said to be thirty feet; the bottom, so far as can be learned, is almost even, so that from the deepest part to the shores the diminution in depth is remarkably gradual.* The shores are for the most part comparatively low, the water-line sandy, affording unlimited beach. Hard by on the west lie Marble lake, Hottes lake, and Little Spirit lake, separated by only the shortest distance from the main body of water, but draining one into the other and north-at length, however, tributary to Spirit lake. Those interested have in recent years cut a channel to bring Little Spirit lake and its congeners into more direct communication with the larger water, apparently with small success. In dry years no lake has anything to spare. Strangest of all, in the middle of the series, in the south half of section 17, lies Sunken lake, distant from Spirit lake only a few rods, and parted from it by a wall of drift some twenty or thirty feet high and at its summit scarcely a rod in width. So abrupt are the shores and so peculiar the situation that common rumor asserts the lake a matter of recent formation; some people even declare that so lately as twenty years ago trees stood where now the water is ten feet deep. The name Sunken lake records the popular estimate and explanation of the remarkable phenomenon. It seems probable, however, that Sunken lake is as old as any of the others, and while a most remarkable bit of topography, sufficiently wonderful to demand, even peremptorily demand, an explanation, yet is it

\footnotetext{
*These purtieulars ara from the reports of fishermen and box'm 3 a ah sut the lake,
} 
quite in harmony with its entire surroundings, and not without parallel in many only less conspicuous cases. For instance, on the east side of East Okoboji lake, in the southwest quarter of section 15, Center Grove township, there are two small lakes even nearer the principal lake than in the case we have just considered and similarly walled off from the greater body of water by a pile of drift. Similar situations on a small scale may be pointed out in every part of Dickinson county. The only explanation is the unevenness of the lower surface of the ice-sheet which rested here, advanced no further, and as it melted retreating ever farther and farther northward, left behind, perchance as blocks of ice, these pools of clear, fresh water. Sunken lake may then represent an ice bowlder; this seems more probable since its walls are steep, unbroken on every side.

Okoboji.-South of Spirit lake lies Okoboji, in its two sections stretching somewhat in the form of the letter U, open to the north, partly in Center Grove, partly in Lakeville township. West Okoboji, which represents the western side of the $\mathrm{U}$, lies almost wholly in Lakeville.* This is by many estimated the most beautiful water in the series. Its greater depth, more picturesque winding shores give it some advantage over Minnewaukon, although the latter shows the greater expanse of water. West Okoboji lake, or simply Okoboji, as it is commonly called, extends nearly six miles in greatest length and almost three at the point of greatest breadth. The greater portion of the lake is, however, narrower, so that the total area does not exceed seven square miles, while its irregular contour measures nearly eighteen miles, as platted. The depth of the lake varies very much at different places and is variously reported. The bed of the lake probably resembles the topography of the adjacent country; it has its hills and its valleys. There seems no reason to doubt that there are many places

*West Okoboji seems to have been named Minnetonka by the Sioux. Okoboji then applied to what we now call East Okobojl. Minnetonka was azd is the name of a somewhat celebrated lake in Minnesota. To avold confusion the Iowa "Mlnnetonka "was abandoned. 


\section{8}

GEOLOGY OF OSCEOLA AND DICKINSON COUNTIES.

where the depth is at least 100 feet, but soundings of two or three times that depth are reported.*

The shores of Okoboji are for the most part high walls of bowlder-clay and drift; sandy beaches are less frequent. Everywhere the erosion of the waves has shaped the shores,

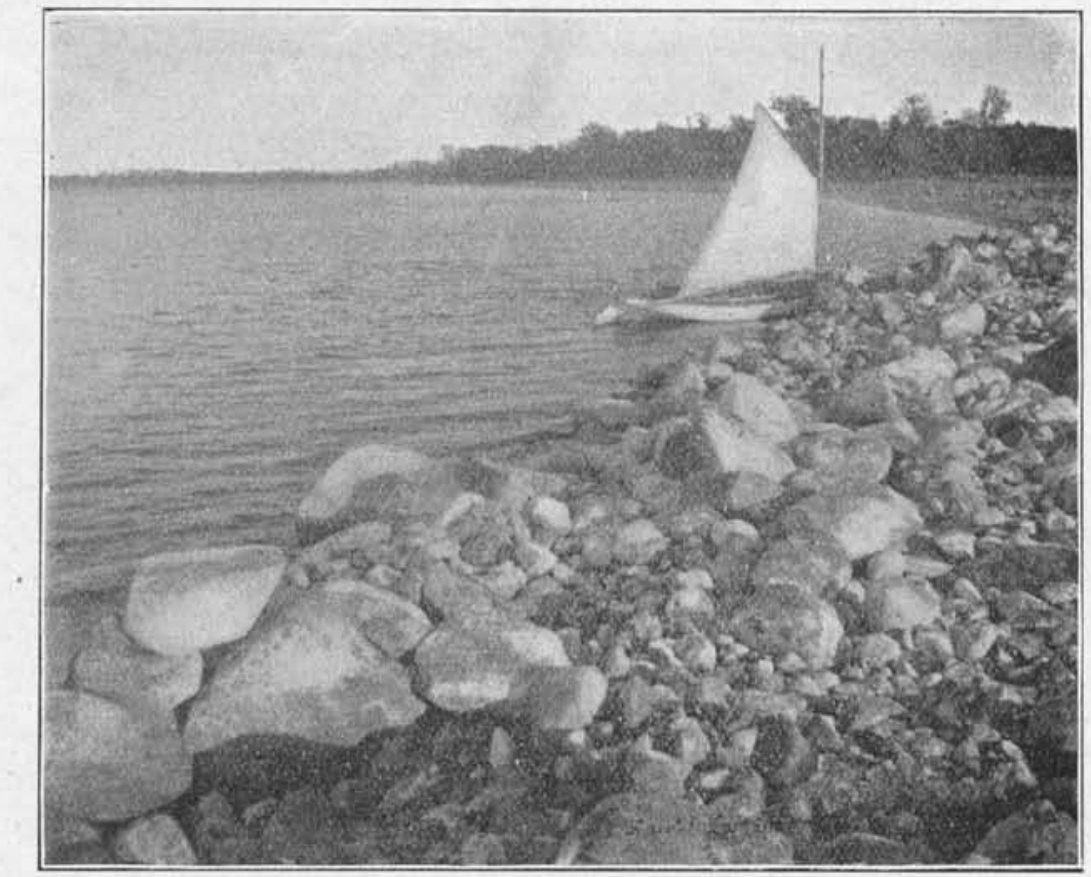

F1G. 20. Natural rip-rapping. shores of Okobojt.

undermining them and sorting their materials; the fine clays have been carried "out to sea," while the weighty bowlders are left behind every winter to be pushed up closer and closer by the ice, at length piled over one another in ramparts and walls, often riprapping the shore for long distances as if to simulate the work of civilized man. A beautiful illustration of this is seen along the southern shore of Lake East Okoboji, section 20. The less attentive observer would surely conclude that those stones were piled up by "art and man's

\footnotetext{
*The only authentic measurements we have at present were made by Mr. P. C. Myers, actIng for the Botanical Laboratory of the State University. Mr. Myers found a depth of 185 feet at a point midway between Ft. Dodge Point and Miller's Bay.
} 


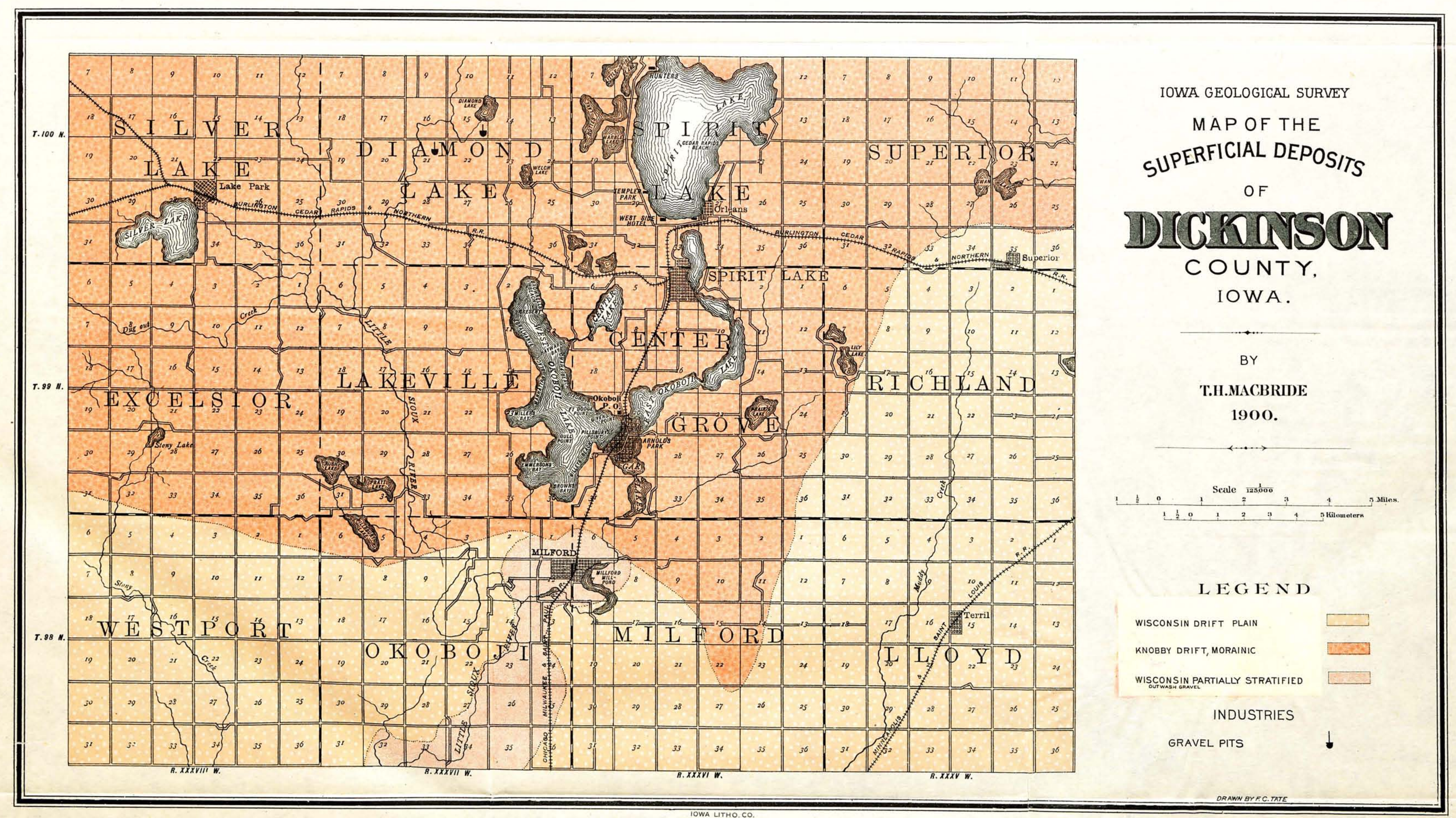


device," a sea-wall to prevent further encroachments of the tide. At the southern end of Okoboji, near Gilley's Beach, is another fine display of bowlders, notable not so much perhaps for their position as for their variety and beauty. Here are bowlders of limestone, bowlders of granite of every sort, porphyry, syenite, trap, greenstone, quartzite, what you will, the debris of all northern ledges. Similar deposits are visible all around the lake, more especially on the eastern side, probably because the prevailing winds being westerly, the waves have exerted their more constant energy along the eastern bluffs.

East Okoboji lake extends from the most eastern point of Okoboji proper in an easterly direction for the distance of two or three miles, then bends to the north or northwest to meet the southern extremity of Spirit lake with which, without doubt, it was formerly connected. East Okoboji is nowhere very wide, perhaps a mile at the widest, generally not more than half a mile, but its length is considerable, nearly seven miles, or with its southern extension into Gar lakes, nearly ten. It reminds one of some noble river; it is like the Rhine with its frequent turns and narrows and the wooded slopes and hills that come on either side down to meet the water. It is a channel, the outlet of Minnewaukon and all its tributary lakes, marshes, ponds and pools, away in Minnesota, almost to the headwaters of the Des Moines. Yet is it not erosional; it is a valley of construction; it was here ere ever the currents that now on occasion pass this way began to flow. In fact the effect of current, such as there is, is quite the reverse of erosion; it is filling the channel, gradually leveling up from north to south this great depression. To the same end contribute all streams that come in from the shores, flushed sometimes with storm-water from the surrounding slopes. There are fortunately not many of these. But in days gone by the intermittent overflow of Minnewaukon delivered to the upper end of eastern Okoboji a large amount of sand, and the shallow waters are now rapidly filling up with vast quantities of aquatic vegetation. 
These lakes taken all together form one of the attractions of Iowa. Their preservation in their pristine beauty is a matter of more than local interest. The waters themselves are not private property; they are under state control, and the state may very properly from time to time take action to prevent deterioration and destruction. The lakes in the vicinity of the town of Spirit Lake should be dredged, and measures taken to prevent the further entrance of erosive products. Steps also should be taken to control the level of water in the entire system as far as this is possible. The cost of such improvements as are here suggested would be small, insignificant, when compared with the good to be accomplished.

The Gar lakes extend from East Okoboji lake southward. They are three in number. An artifical channel connects the first (northernmost) of these with East Okoboji; a marsh connects it with Minnewashta, the next lake south, while the third in the series is joined to Minnewashta by a shallow channel through which, at moderate stages of water, the wind drives the waves and eurrents now in one direction now the other. The total length of the three lakes is about two miles, and they cover altogether an area of perhaps a square mile. Nevertheless they are not simple expansions of the drainage outlet of the larger lakes; they, too, occupy constructional valleys of depressions. Middle Gar or Minnewashta, has a reported depth of twenty feet, is a very pretty body of clear, pure water. The two others in the chain are much shallower and much afflicted with water weeds. Indeed if one may judge by present appearances, it seems likely that a ridge of drift once separated Minnewashta from Lower Gar, and that this has been removed as much by the beating of the waves, now on this side now on that, as by any other cause, as erosion. The more one investigates the problem, the more he will be disposed to the conelusion that the lakes, as a series, suffer diminution by evaporation chiefly; by overflow under exceptional conditions only, as of unusual rainfall, freshets and so forth, and even then the escape of the waters must be excep- 
tionally slow, for the outlet seems to show practically no erosion. The thrust of the ice in winter,-ice two or three feet in thickness is said to be not unusual,-would, however, here as in the case of Spirit lake tend to rebuild the barrier between the lakes, even supposing erosion in spring or summer to have deepened somewhat the channel. It will be observed that the line of drainage, such as there is, lies through Spirit lake, East Okoboji and the Gar lakes. This is one reason, no doubt, for the great difference in depth shown when we compare the two principal lakes. Okoboji is out of the line of drainage entirely, always has been, and has almost no affluents. The two small streams that enter, one from the north, one from the south, bring with them at present almost no erosive material, the surface which they drain being yet grass-covered. Another cause for the difference between the great lakes in depth will be discussed in connection with the general topic, stratigraphy.

Cénter lake, lying chiefly in section 7, Center Lake township, deserves mention in this connection. It is a bright, sparkling sheet of water of considerable depth, evidently permanent. About one mile and a quarter long, and three-fourths of a mile wide, bordered on the east and southeast by a fringe of woods, it constitutes an attractive resort, though somewhat isolated and likely to be overlooked by the summer tourist. Center lake approaches to the southeast to within half a mile of Okoboji, and by a shallow marshy outlet is connected with the larger water.

The smaller lakes.-Besides the lakes in the central part of the county, the Minnewaukon and Okoboji system, Silver lake, Diamond lake and Swan lake, are topographic features likely to be permanent. The first named is a beautiful body of water, in the township of the same name, covering perhaps 1,000 acres, and has a reported depth of twenty feet. Diamond lake and Swan lake are much smaller and shallower. Stony lake, in Excelsior township, is a small body of water with marshy extensions surrounded by precipitous hills. The 
water is reported fifteen feet deep. Pratt lake and Sylvan lake are larger but shallow, the latter a mere rush-covered marsh. Pillsbury lake, close by, is this year [1899] a beautiful sheet of water five or six feet deep, and a mile in length, but is reported inconstant. These three lakes have peculiar drainage to which reference will be made later on. Other small lakes in the county covering from eighty to 100 acres, some of them nameless and some of them not, are little more than persistent marshes for which thus far the agriculturist has found no convenient method of drainage.

\section{DRAINAGE.}

Dickinson and Osceola counties, though by no means lacking, as we have seen, in inequalities of surface, yet exhibit in very many places a remarkably incomplete drainage. The country in fact displays everywhere all the signs of newness, geologically speaking. Time, since the deposition of the later drift, has not sufficed to enable the streams or storm-waters to cut the necessary valleys back across the plateau or among: the hills for the effective draining of the thousand minor depressions that everywhere mark the surface. Many of these perhaps never would be drained, at least by ordinary processes; such, for example, are the greater lakes we have just been studying; but there are hundreds and hundreds of minor pools and ponds that require time only when erosion effected by their natural overflow shall put their waters in connection with some neighboring stream and bring about at length their complete obliteration. The curious student may find examples everywhere. For instance, at the top of the hill in the Sw. $\frac{1}{4}$ of Sec. 20, Tp. 100 N., R. XXXVI W., near the highway is a pond which lacks but a little, one would think, to be entirely emptied down the hill, yet it may require some time before natural causes effect that thing. A similar pond lies near the top of the hill in the Sw. $\frac{1}{4}$ of Sec. 32, Tp. 100 N., R. XXXVII W. Here is a small lakelet fully seventy-five feet above the river valley, passing through the same section! Such a situation cannot in the nature of things be permanent, 
and yet time enough has not elapsed since the formation of that pool for its obliteration. A more striking instance still, if such be sought, may be observed near the bridge in section 33 of Lakeville township. Here is a small lake sufficiently deep, not more than a rod or two remote from the banks of the Little Sioux, and yet even this has not been undermined and swept away by the erosion of that stream. Tempusedax remum; the tooth of time it is that must elaborate the world and bring its rudeness to perfection.

Nevertheless Osceola and Dickinson are not without their creeks and rivers; the highlands are in the north and the general course of drainage to the south. However, the watershed of the northwestern part of Osceola county is to the west or southwest, and of the northeastern part of Dickinson to the north. The principal streams of the two counties may be enumerated from the west. The Little Rock river enters Osceola at the extreme northwest corner of the county, flows south less than a mile from the county line for three or four miles, then turns abruptly west, its waters drifting at length into the great Missouri. Otter creek next, takes origin in a marsh just west of Bigelow, Minn., near the state line, enters Viola township, passes Sibley on the west and south, and presently turning southwest emerges from Osceola county exactly at its southwest corner, only finally to contribute its waters to the Little Rock. East of Otter creek are one or two small streams which find their way southward and become tributaries of Floyd river, which also joins the Missouri near Sioux City. But the principal stream of Osceola is the farfamed Ocheyedan, a prairie river, narrow and rather winding in tortuous fashion through a constructional flood-plain, generally wide and far-expanded, sometimes narrowed to a gap between the hills. This in two branches crosses diagonally Osceola county entire. The principal stream takes origin in marshes just east of Bigelow, Minn., receives several minor tributaries from the east, one of which is the outlet of Rush lake, in Harrison township, is joined by its principal 21 G Rep 
western affluent, the Little Ocheyedan, and finally leaves the county about one and one-half miles west of the southeast corner of the county. The Ocheyedan drains the summit of the Altamont moraine which we have already described, what might, not without impropriety, perhaps be called the Ocheyedan moraine. For the most part an insignificant stream, near its mouth particularly it has effected considerable erosion. Judging from what we see to-day the valley of the river must have remained filled with ice until very late in the process of glacial retreat. Beds of gravel of aqueous deposition high above the flood-plain of the present stream, as in Sw. $\frac{1}{4}$ of section 17, Tp. 98 N., R. XXXIX, W., indicate that floods of water once passed entirely across and above the broad valley in which the prairie river now threads its course. We shall find oceasion to refer to this again in speaking more particularly of the drift formations of this region. The amount of erosion effected by the stream since that earlier day when first it found itself draining a wide field of slowly disappearing ice has been, as would appear, comparatively small. Its destiny has from the first been well determined by a wall of pebbly drift, for the most part typical Wisconsin, completely hemmed in has it been by an insurmountable barricade, until reinforced by the waters of the upper Little Sioux, near the center of Clay county, it finally breaks the barrier and starts under the name of the latter river in the direction it has all along been seeking, off to the south and west.

The topography of Dickinson county is, as we have seen, much more irregular than that of Osceola, and the streams are proportionately more tortuous, especially in the western and central portion of the county. While the drainage as a whole is southwards, the water courses flow in almost any direction and present some very peculiar situations. The principal streams are Stony creek, the Little Sioux river with its tributaries, and Muddy creek. The first takes rise in Stony lake and derives its name from its bowlder-walled fountain. For the greater part of its course through the townships of Dickinson county, the stream is little better than a 
marsh or quagmire. After it escapes the hills that immediately guard the lake to the south it simply forms a great slough extending diagonally across Westport township. The land on either side, however, is higher and the township otherwise pretty well drained.

The Little Sioux river is a much more considerable stream. Rising in the marshes of Jackson county, Minn., it enters Iowa by two branches, which, however, soon unite, and traverses Dickinson county in labyrinthine fashion from north to south, emerging near the center of the south line of Okoboji township. The east branch winds back and forth in the east tier of sections in Silver Lake township, receives as principal tributaries the outlet of Silver lake and Dug-out creek, - a stream whose very name indicates a popular appreciation of the rigor of our present physiographic problemand finally meets the east fork in section 7, Lakeville township. Dug-out creek rises on the border of Osceola county not far southeast of the town of Harris. Its upper course is comparatively uneventful, but after leaving section 9 of Excelsior township it falls in with a tumultuous throng of precipitous morainic hills through which it appears to have literally dug its way. The creek amid the hills serves to bring into connection and so drain, very imperfectly, a series of marshes; otherwise its valley is very narrow and its waters with every freshet are still digging away at the stubborn ridges which still rise on all sides largely unaffected, everywhere to deflect the channel, now this way now that, to every point of the compass.

The east branch or fork of the Little Sioux is much the larger and may be esteemed the principal stream. It crosses with perennial waters Diamond Lake township, receiving on the way the overflow of Diamond lake, if such there chance to be. In this upper part of its course the stream is chiefly remarkable for the great disproportion which exists in many places between the size of the stream and that of the valley in which it lies. The valley is constructional; for instance in 
sections 21, 29, 32 of Diamond Lake township. Where not constructional, especially after the union of the two branches, the valley of the river is narrow enough. Compare its course in sections 10, 15 and 16 of Okoboji township; indeed in all the northern part of this township. Here the river simply winds about among the hills checked on every hand by banks of Wisconsin drift, turning south through section 10 it makes a long detour of several miles only to return again to a point within less than half a mile of its southward moving waters before it finally emerges into the gravel plain and valley of the outlet of the greater lakes. In fact the topography of Okoboji township throughout is exceedingly complex and deserves much more consideration than it has here received. Near the middle of section 4 , the river receives the outlet of Pillsbury lake; that is of the three lakes of the Pillsbury series. Platt lake, the most easterly of the three, extends east to within less than a hundred rods of the river. Nevertheless Platt lake drains northwest into Sylvan or Rush lake, this again south into Pillsbury lake, whence the drainage passes southeast for a mile or more among the hills, then turns north and northwest and enters the river through the channel of a little stream flowing from the southeast, which is again almost continuous with another drainage channel leading to the southeast.

After its union with Okoboji outlet the river traverses the Milford gravel-plain, through which it has carved a channel, until near the south line of the county, and in sections 33 and 34 it meets again a morainic ridge and is deflected westward and then southwestward, and so leaves our territory.

The outlet of the greater lakes, Okoboji outlet, follows as heretofore stated, a constructional valley among the hills until it strikes the Milford gravel in the northwest corner of section 7, Milford township, and possibly further, even to the middle of section 18. In the gravel the stream has already effected considerable erosion, notably east of Milford and in the vicinage of Okoboji Mills. 
Muddy creek, the only remaining stream of any considerable size in Dickinson county, is for the greater part of its course a typical prairie slough. It rises in marshes in section 3 of Richland township and drains in most imperfect fashion this and Lloyd township farther south. After passing Terrill in the latter township, the stream occupies a broader and more definite valley, becomes a pleasant water course marked here and there by gravel terraces, after the manner of all southmoving streams in this part of Iowa.

\section{STRATIGRAPHY.}

FORMATIONS REPRESENTED.

The geological strata offered for study in Osceola and Dickinson counties are of the fewest. There are no traces whatever of the presumably underlying Mesozoic and Paleozoic formations. In fact all evidence goes to show that the drift in this part of Iowa is deep, hardly pierced even by the well-drillers who elsewhere always have some account to give of underlying rocky strata.

Mr. Meader, of Sibley, reports a well constructed by him south of Allendorf, in Osceola county, 515 feet deep, terminating in gravel. On the other hand there are reports [unverified] to the effect that some deep wells in the same county reached a definite sandstone. This perhaps indicates the Dakota sandstone, since that horizon is reported from Esther: ville at a depth there of 234 feet.*

The geological formations represented in the two counties now under consideration may be tabulated in accordance with present knowledge, as follows:

SYNOPTICAL TABLE OF GEOLOGICAL FORMATIONS.

\begin{tabular}{l|l|l|l}
\hline \hline \multicolumn{1}{c|}{ Grour. } & \multicolumn{1}{|c|}{ SYSTEM. } & SERIEs. & \multicolumn{1}{c}{ StAGE. } \\
\cline { 4 - 4 } Cenozoic. & Pleistocene. & Glacial. & $\begin{array}{l}\text { Wisconsin Gravel. } \\
\text { Wisconsin Drift. } \\
\text { Kansan. }\end{array}$ \\
\hline
\end{tabular}

* See volume VI of this series, p. 197. 


\title{
GEOLOGICAL FOR MATIONS.
}

\author{
GLACIAL SERIES.
}

Kansan Drift.-To the Kansan is here provisionally referred all the drift that is known to lie underneath the Wisconsin. This, so far as is known, is discoverable nowhere within the present limits by a natural exposure. But the testimony of well-diggers consistently affirms the existence beneath the superficial "gravel-dirt" of the vast beds of blue clay overlying beds of gravel. At Allendorf the blue clay is reported 250 feet thick. A few miles further south the blue clay is said to be 150 feet thick, while on about the same meridian near the county line the same stratum is described as 100 to 150 feet thick. In Dickinson county the presence of the blue clay beneath the ordinary drift is everywhere recognized and reported, but no data were secured as to its thickness; so far water seems obtainable upon its upper surface. Thus on Milford plain wells are sunk in the gravel to the blue clay with abundant water. In the western part of the county the blue clay is reached at a depth of no more than thirty feet. On the other hand, attempts to pierce the blue clay have been made in several places near the lakes with apparently small success. After going through the tough bowlder-thronged material for a distance of 150 to 250 , or even 300 feet the operator seems, in all cases, to have abandoned the attempt and to have gone his way discouraged. But in any event, even with present data, we have every reason to believe that a comparatively thick sheet of blue clay, more or less charged with bowlders, underlies the superficial deposits of the whole of both counties. The thickness doubtless varies, but data are not yet fortheoming in number sufficient to enable us to say at present how or in what direction the variation occurs. But even with present imperfect knowledge of these hidden deposits we have hints of layers, stratification below the unoxidized clay. The well at Allendorf is 515 feet deep, and the record there, though not as accurate as could be wished, is yet very 
suggestive. The surface drift is reported twenty feet deep; blue clay, about 250 feet; then sand and gravel; then yellow clay, about 200 feet; the gravel again, in which was found the sought-for water. There are other reports of similar import, but lacking details of measurement, so that it seems certain that one day the surface deposits of the region we study will be regarded as made up of at least three members, however these may ultimately be correlated with similar formations elsewhere in the state.

In the second place we describe in this connection, and so would refer to the Kansan drift-sheet, certain loess-like formations already mentioned in our study of the topography of the southwestern part of Osceola county. These deposits occupy a large part of Gilman township adjoining parts of Holman and Baker. The topographic features of the region have already been discussed. Their peculiarities, as contrasted with the topography of the adjacent country, have been accounted for on the supposition that the surface has been longer exposed to the wear and tear of time, of storm and flood. As to structure the characteristic Wisconsin is notably absent, though thin traces of it anon appear. The subsoil is everywhere, so far as observed, and likewise so far as reported, a stiff yellow clay with few bowlders or pebbles or absolutely none. In fact the country is loess-covered for a considerable depth; in some places, if the testimony of well-drillers may be taken, to the depth of twenty feet. Underneath again is the blue clay. It seems probable that we have here an uncovered portion of the original surface on which further north and east the Wisconsin was laid down. It is perhaps partly the oxidized and partly the loess-covered surface of the blue clay. We have here to do with a sort of limbus, a border-land, where owing to the very nature of the materials with which we deal, lines of accurate limitation are difficult to draw. Such lines may one day be drawn, but it will be after a most careful study of this whole area, section by section and field by field. 
WISCONSIN DRIFT.

The Wisconsin deposits in Osceola and Dickinson counties present themselves under two distinct phases; the typical Wisconsin bowlder clay and a deposit of coarse sand and gravel, in places not few, superimposed upon the first. In general the Wisconsin clays, pale in color, surcharged in richest profusion with calcareous granules and pebbles, bearing abundant, often gigantic, unworn bowlders, cover the whole territory in question, with the notable exception of the limited portion of southwest Osceola county, to which reference above has just been made. The deposit is generally of indeterminate depth, so irregular is the topography; it is piled in the hills, buried in swamps, raised in long ridges, and again spread out in gentle declivities. Fine exposures are seen along the bank of Little Rock river, in the northwest corner of Osceola county, along the line of the B., C. R. \& N. railway east of Allendorf, nor less at the bend of the Little Sioux river in Okoboji township, Dickinson county; and so almost everywhere where the surface soils have been removed in railroad building, or in the improvement of the common highway. Bowlders of every shape and sort are strewn in liberal profusion. These are commonly granite, but limestone is not wanting, and in some localities small, angular fragments of Sioux quartzite preponderate. These have been referred to as shown along the shores of Okoboji. In attempting to estimate the thickness of the deposit the best, in fact almost the only, data are those of the well.digger. In few instances, as in the railway cuttings west of Ocheyedan river, we may form some conclusions by comparing successive sections. Here the depth is fifty feet or more. The average for the county is probably much less. In the more level parts of Osceola the record of wells would indicate no more than fifteen or twenty feet as the thickness of the true Wisconsin, and even this surely diminishes rapidly to the southwest, though unevenly, until seen at length in scattered patches only, it vanishes entirely. Planed pebbles are not infrequent, 
and in the better exposures small pieces of limestone with fine glacial marking may generally be collected. The morainic hills of both counties are generally piles of typical Wisconsin drift, though not infrequently gravel-capped and. sometimes gravel throughout, at least as far as can be observed, as for example, the Ocheyedan mound and certain small hills near Diamond lake and elsewhere.

This leads us to consider the second phase of the Wisconsin deposits in our present field. The contrast between the two could not easily be more pronounced. The deposits we have been describing are typical glacial clays; their materials are indiscriminately mixed, heaped and tumbled, crushed and rolled together, big and little, coarse and fine, without any order. assortment or arrangement whatsoever. The terrace or gravel deposits, on the other hand, are all laid down with uniformity more or less pronounced, are all stratified, their materials assorted, arranged and re-arranged as by aqueous agency. The materials besides are all water-worn and their peculiar distribution, as we shall presently see, can lead to no conclusion other than that these deposits were laid down as the debris of former streams whose channels even yet may here and there be noticed, and measured by the islands and sand-bars they have left behind. These streams were glacial streams, they were coincident with the final retreat of what we have been calling the Wisconsin sheet when it had, in our region at least, been for many years reduced to no more than a series of gigantic glaciers lying in the constructional valleys of which mention has been made. As every one knows who has even watched the behavior of even the smallest streamlet, the finer materials are always swept away, deposited far down the stream, while sands and gravels are piled up in regular order wherever the valley widens or the current becomes in any locality for any reason less efficient. So the sands of Milford plain fill up a wide constructional valley, widest near Okoboji Mills and narrowing, as we have seen, at its exit from $22 \mathrm{G}$ Rep 


\section{GEOLOGY OF OSCEOLA AND DICKINSON COUNTIES.}

the county. Into the preformed valley the sands from melting ice were swept, filling it from side to side to a depth of fifty, perbaps sixty feet, as one may see who stands on the hill-top south of the hills referred to, and looks across the valley of the Little Sioux and marks the long straight line of terrace on the western side; or he may note the benches further south in section 33 where the subsequent erosion of the river has left them bracket-like, high up on the sides of the bordering hills. Furthermore the streams that accumulated Milford sands seem to me to have been possibly, in part at least, super-glacial streams; they passed along on top of the ice. No streams in volume adequate to the effect could have passed down the valley of the "outlet" without showing more characteristic signs of erosion than now appear. But the deposits in question begin near the mouth of the outlet as if at the time of their deposition a glacier lay in all the valley occupied by the present lakes, extending even far down the outlet. Over this icy mass swept down the stream or streams that brought in part, at least, the debris that fills the Milford valley. It may be remembered in this connection that glacial ice, especially morainic or marginal ice, is seldom pure; it is often covered with morainic materials, filled with sand-bowlders and the gathered accumulations derived from the surface of its transit. It is difficult on any other theory to account for the distribution of the deposits which seem in otherplaces to represent the formation now considered, for these gravels are by no means confined to Milford plain; they are scattered over our entire area, often, generally, far above the course of any present drainage system, entirely out of reach of any recent waters. Yet there they are all water-laid, stratified, cross-bedded even, in unmistakable fashion. For instance, on the top of the hill in the Nw. $\frac{1}{4}$ of the Ne. $\frac{1}{4}$ of Sec. 17, Tp. $100 \mathrm{~N}$., R. XXXV, W., there is a gravel-pit which shows all these peculiarities, and there are many others across the northern part of Dickinson county, near Diamond lake, and indeed throughout the hill-country. In Osceola we have the 
great Ocheyedan mound, not to speak of others, the upper part of which, 150 to 170 feet above the present stream, is made up of stratified sands and gravel. Across the Ocheyedan valley in the Sw. $\frac{1}{4}$ of the Se. $\frac{1}{4}$ of Sec. 17 , Tp. 98 N., R. XXXIX, W., a cut in the highway shows the same phenomena. More

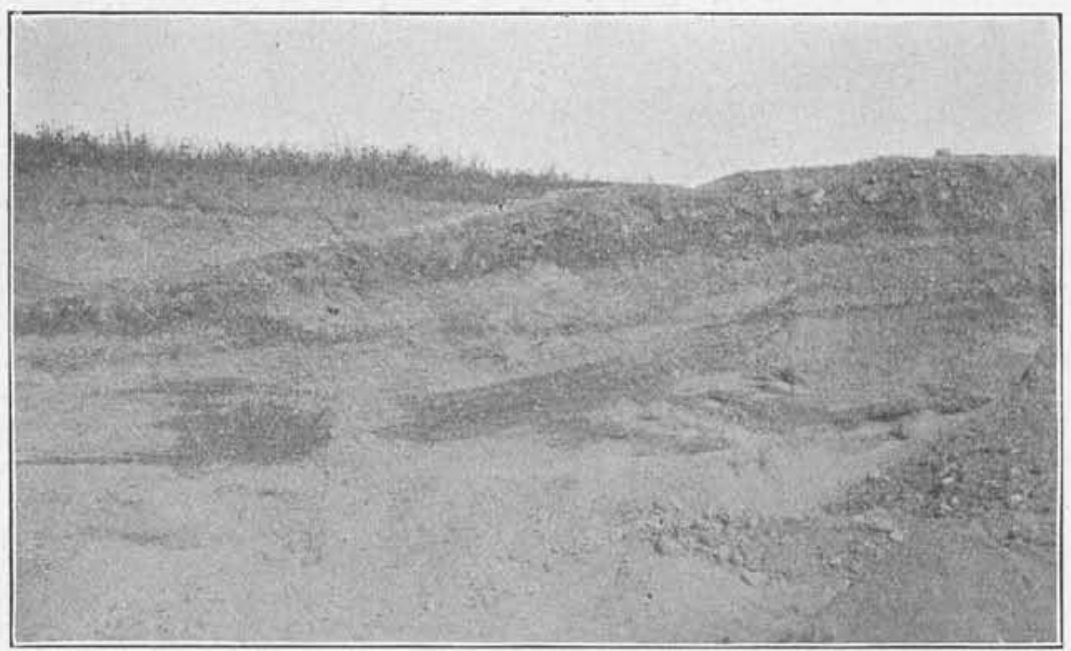

Fig. 21. A great pile of debris-the Sibley gravel-pit.

remarkable still is the great pile of such debris which forms the famous Sibley gravel-pit (Fig. 6). Here is a deposit twenty or thirty feet in thickness far away from any present water channel, but plainly of water-laid materials, resting unmistakably upon the uneven surface of the Wisconsin drift, for the contact has been in more than one place exposed. The only explanation of the gravel-pit is to be found in the carrying power of some broad drainage current flowing across the Allendorf moraine to find its outlet in the broader valley of Otter creek as it widens a mile or two southeast of Sibley.

Similar beds of gravel occur along the course of that stream, as in the Nw. $\frac{1}{4}$ of Sec. 29, Tp. 99 N., R. XLIX W., and so at Ashton, and ten or twelve miles further south where the gravel-pit of Sheldon exhibits the same characteristic features. The Ocheyedan mound, so far, at least, as affects the part of 
it composed of gravel, must likewise have been heaped upon the ice or in the ice at a time when the Ocheyedan basin to the west was solid and full. Later on when the drainage began to follow the course of the Ocheyedan river, perhaps across the foot of the melting glacier, other correspondent or similar gravel terraces were laid down which may now be noticed along the banks of the present stream, twenty or more feet above the present flood-plain; as, for instance, immediately west of the mound on the west side of the river. The gravel in all the cases referred to, in fact in all cases observed, exhibits features of an ancient type, and one would be inclined at first to think it for this reason pre-Wisconsin. But there is no doubt of its horizon; it is post-Wisconsin. The material is doubless, some of it, from similar deposits of much greater age, and the rotten bowlders with which it is charged [see figure] may be thus accounted for; or we may apply the explanation suggested by Bain," that the weathered bowlders are chiefly of the coarser micaceous granite, hence of the more quickly perishable sorts. In any case it is to the ordinary observer a matter of surprise to note how completely in hundreds of instances in the case of granite bowlders adhesion has broken down, so that through them the spade or shovel of the laborer goes as through compacted sand.

These gravel-deposits, as here described, ought to be reckoned as a distinct formation. As regards the true Wisconsin drift, they represent conditions entirely distinct and different. They stand to the Wisconsin, it would seem, precisely in the same relation as to the older Kansan stands the Buchanan gravels.

\section{ECONOMIC PRODUCTS.}

The economic products of this part of Iowa are not numerous. Its wealth is found in the exceptional natural fertility of its soils. Nevertheless we may here enumerate building-sand, gravel ballast, brick clay and native wood suitable for fuel. 
SOILS.

The soils of the counties before us are of two distinct types according with the stratigraphy above described. Thus in the Milford plain, and wherever gravel terraces have to any extent been formed, we have a light but warm sandy soil, fertile and usually productive save in seasons of prolonged drought. The advantages and disadvantages are those of sandy soils everywhere. The total extent of these soils, however, is comparatively small. Over the greater part of our area we have the rich black surface soil which characterizes nearly all the region of the Wisconsin drift in Iowa, a soil adapted to easy tillage, to the cultivation of every sort of staple crop. Underlain with a sub-soil peculiarly rich in lime, the region is especially advantageous for the production of wheat. The greater altitude, 1,000 feet above the prairies of the eastern part of Iowa, and the higher latitude, give in summer a much cooler climate, which contributes greatly to a generous harvest of the standard grain. The marshes and swamps, left incomplete by the peculiar conditions of their formation and rapidly yielding to the skill of the engineer, are everywhere subject to successful tile-drainage, and as is usual in such case will soon form part of the most fertile lands in the country. Even the steep hills of which these two counties have more than their share, afford pasture lands in quality unexcelled. There are practically no waste lands, and fine homes and barns and thriving towns afford on every side the most abundant and satisfactory evidence of successful agriculture.

\section{SANDS AND GRAVELS.}

The old river-terraces and outwashed gravel-plains and mounds furnish in all parts of the country supplies of sand suitable for the builder, while the gravel with which the sand is uniformly associated is useful in the construction of walks, of concrete for foundations, culverts, and in all places where artificial stone is to be manufactured. No ledges of rock are 
exposed within these counties. Foundations are very commonly constructed of bowlders, which recent methods of handling render perfectly tractable and convenient.

The gravel also is of the utmost use in railway construc: tion. Thousands of car-loads have been made use of by the two lines of railway having access to the gravel pit at Sibley. The gravel is likewise of that peculiar constitution which makes it of supreme value in the construction of roads and highways. Sibley, with the minimum of cost, may have the very finest of streets, and the whole region now under discussion needs no more than judicious management to have in time, with very limited outlay, a perfect system of rural highways.

\section{BRICK CLAY.}

So far as could be learned no brick is now manufactured in either county. The Wisconsin clays are not good for brickmaking. But there is every reason to believe that good working beds of brick clay may yet be found in the southwest part of Osceola county where exposures of loess are not wanting. Investigation in the vicinity of Ashton, and especially toward the west and south, may be confidently expected to discover beds of loess thick enough for practical work. In the swales of small creeks occur sometimes beds of clay that appear promising. One such may be examined in section 6 of Goewey township, about one-half mile north of the Sharbandy schoolhouse. In any case it would seem the part of wisdom if those who construct wells or make excavations in the district named should be on the lookout for material in this county so much to be desired.

FUEL.

No coal is reported in these counties, nor is any likely to be encountered. The accumulated drift seems to be everywhere very deep, and there is no evidence that the usual coalbearing strata extend so far north.* The only fuel supply now in sight for this part of Iowa is found in the groves of

*There is an unverified report that coal has been discovered near Estherville. 
timber, either native or planted. In Osceola county at the time of its settlement native trees were exceedingly few; over the greater part of the county not one. However, there seems to have been a limited number of forest trees about the south end of Iowa lake, Fairview township, and in the center of Grove-island lake there appears to have been a considerable growth of Ash and possibly of other species. The lake named was a wide marsh, now drained, but the grove is still extant. Dickinson county was much better supplied. Fine stretches of forest stood about the larger lakes, especially in Center Grove township. Trees of considerable size furnished the early oceupants of the county with not only abundant fuel but with lumber, and so made house-building possible at a time when it had been difficult, if not impossible, to obtain building materials from localities remcte. The original forest trees in every locality are largely gone, but extensive areas of second-growth still furnish a source of fuel supply very convenient to a large number of people. But native resources of this sort have long since ceased to be the principal recourse. Planted groves dot the universal prairie, and every farmer finds on his own land a timber and fuel supply of greater or less value, according to the extent and variety of his planting. A list of the forest trees now growing in the district is appended further on.

WATER SUPPLY.

The water supply of this part of the state is chiefly in wells. Not that there is lack of streams, but these, as has been seen, are not large or numerous. Little Rock river is a fine stream, in the extreme northwest of Osceola, and the Ocheyedan and Little Sioux are convenient and unfailing. The abundant lakes in Dickinson county are of inestimable practical importance. But wells are everywhere in use even for watering cattle, and have been found so far very easy of construction. In few places have deep wells been tound necessary.

The streams of the region are little used for purposes of water power. Such use has been attempted in several places, 
notably at the outlet of Spirit lake, at Milford [the old town], at Okoboji Milis, but none of these efforts are now in successful operation. The constant volume of water is perhaps nowhere sufficient to afford for such enterprises any great promise for experiment for the future. In natural beauty and attractiveness Osceola and Dickinson counties are second to no other region of the state. But in economic resources they must depend chiefly upon the exuberant wealth of a marvelously fertile and productive soil.

\section{ACKNOWLEDGMENTS.}

In preparation of this report the author has enjoyed the advice and assistance of many of the citizens of each county. Hon. R. A. Smith, of Okoboji, was able to furnish the greatest assistance, having been previously associated with Doctor White in a similar enterprise. The writer would also record his sense of obligation to Mr. O. B. Harding, of Osceola county; Mr. G. B. Meader, of Sibley; Mr. Otto Turk and Mr. J. P. Hawxhurst, of the same city; Mr. A. A. Henderson, of Okoboji; Mr. H. F. White and Mr. J. M. Brown kindly furnished records of elevations for points along the line of the B., C. R. $\&$ N. railway; Mr. D. J. Whittemore did the same for the line of the C., M. \& St. Yaul railway, and Mr. C. W. Johnston for that of C., St. P., Minn. \& Omaha road. Professor Calvin and Mr. Bain of the Survey have been of constant assistance throughout the work.

\section{FORESTRY NOTES FOR DICKINSON AND OSCEOLA COUNTIES.}

Of the conditions by which forest distribution in Iowa was originally limited no better illustrations could be found than those afforded by the situation presented in the two counties of Osceola and Dickinson. Osceola was practically treeless, because fire-swept; the only native grove, as above noted, occupied an island in the middle of a lake! A similar tree colony stood in an exactly similar situation in the midst of a marsh a few miles east in Dickinson county. The number of 
species on these islands is not great. Soft Maple, White Ash, Wild Cherry and Plum are the principal forms now occurring on the islands. Doubtless in the marshes here and therestood a Willow and by the streams perchance a Cottonwood, but aside from such isolated specimens there were no trees in Osceola county.

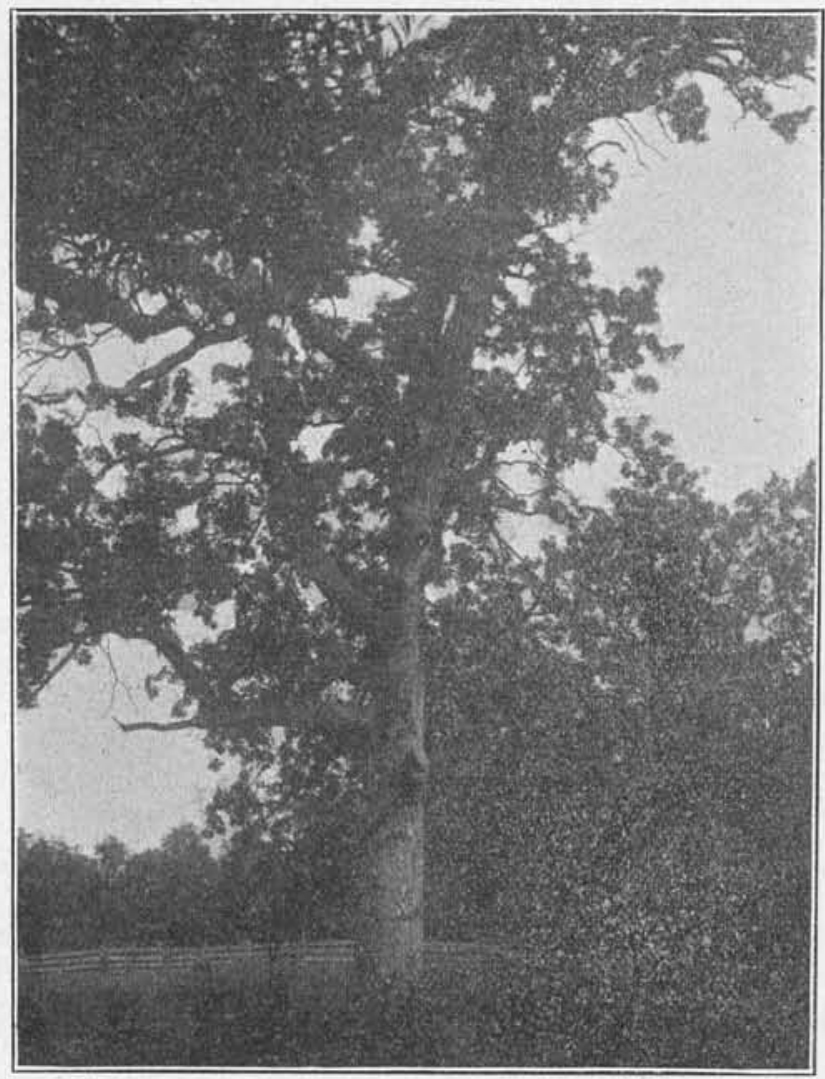

F1G. 22. Quercus macrocarpa Mx. Bur Oak. A few of the primeval trees of large size are still standing.

Dickinson county was much better supplied. In the neighborhood of the great lakes were considerable areas supporting, in some localities at least, a heavy forest. Thus the whole area now platted as Arnold's Park was originally woodland, with trees of large size, furnishing most valuable lumber 23 G Rep 
to the early pioneer. This region is still largely wooded, although the primeval Oaks and Walnuts have mostly disappeared; and there is a continuous fringe of woods along the entire eastern shore of Okoboji, which is doubtless primeval. There was another fine grove east and south of Center lake, the descendants of which still exist in the same territory, with here and there a primeval Elm or Oak. One of the latter has been thought worthy of illustration here. Again, there was a very large tract of woodland east of East Okoboji lake, and this was continuous with a fringe of trees that encircled Spirit lake more or less continuously all around. The woods about Spirit lake were wanting chiefly toward the northeast and north, and were more abundant to the northwest among the lakes and ponds abounding in that quarter. There were also fine groves of native timber in the vicinity of Pratt lake and along the steep sides of the valley of the Little Sioux, more particularly in the center of Okoboji township. At present groves and thickets of second growth in all these places occupy nearly all the earlier forest territory and have probably in later years somewhat extended the original forest limit. The cutting out of the larger mature trees has given opportunity for the oncoming of hundreds of younger ones, and the suppression of autumnal fires has given a chance to every seedling, so that at present the actual number of trees in the region of primeval woodland is probably greater than ever before. Small numbers of native trees were also found on the eastern or southeastern shores of Diamond lake and Silver lake, and in other places not here named perhaps a few. The scarcity of trees in this part of Iowa has in some cases led to the preservation of the woods. Besides, here as elsewhere in Iowa, trees generally oceupy the less fertile and less desirable land, stretches of sand, steep clay hillsides, deep ravines, in short localities which give in their perpetual harvest of wood and fuel the best return of which the soil is capable. Most of the farmers owning such lands appreciate this. In many places, however, the desire to convert such 
lands into pasturefields is making for the destruction of the woods. In some places, even along the lakes, where their esthetic value, if nothing else, would seem to demand their preservation, the forests are being extirpated by the axe, in others by over-pasture; especially have the woodlands suffered during these later years of unusual drought. There are many places where trees of various sorts and kinds have perished simply from drought. This fact should lead the owners of wood-lots to treat them hereafter with greater consideration, if the native groves are to survive at all. The amount of grazing should be limited, and restricted to the winter months if permitted at all. A list of trees native to the region and which may, therefore, be cultivated in this climate with some expectation of suceess is appended.

But for the forestry of our region, an account which would deal with the native groves alone would beincomplete indeed. What was once rightly called treeless Osceola appears to-day as a wooded country from which the farms have possibly been shaped by clearing, so abundant in various places are the groves, so extensive the arboreal plantations. Tree claims in this part of Iowa make a better showing than almost anywhere else. The accompanying illustrations show how completely a prairie landscape may, in twenty or thirty years, be transformed. Piesle's grove in Viola township, northwest of Sibley, is a fine example. The species commonly planted are Cottonwood, Willow and White Ash. The Soft Maple and Box Elder also find place. In many of these groves several other native species are beginning to appear, seeds having been probably dropped by birds. The Wild Grape, Virginia Creeper, Wild Plum, Wild Cherry are among these. In fact it is perfectly evident, proved by experiment, that the prairie farmer may have the advantages of a contiguous wood-lot, in northwestern Iowa, just to the extent desired. Without the planted groves the northwest prairie, storm-swept in winter, sunscorched in summer, had been almost uninhabitable; with the 
groves the severities of climate are so reduced as to make these farms among the most attractive.

The species cited, used in plantations, have the advantage of very rapid growth, and to this extent have served an immediate excellent purpose. The only form of lasting value is the Ash. This tree has all valuable qualities. It is an excellent shade-tree, it makes the best of fuel, and its wood is serviceable for all sorts of purposes on the farm. It should be more widely planted. It is time the Cottonwoods, Box Elders, etc. were gradually supplanted by trees of more valuable, more enduring, species. The accompanying catalogue of native trees furnishes a list from which selections may be made. The Elms, the Bur Oak, the Red Oak, the Hackberry, the Red Cedar or Juniper, the Linden or Basswood, are all indigenous species and certain to thrive if properly protected and cared for. Those farmers who have been so preeminently successful with the less desirable Cottonwoods have already established more or less perfect forest conditions into which the successful introduction of the more desirable hardy trees will be a matter of proportionately small difficulty. With the trees named should be introduced as border trees the Hazels, Crab-apples, Plums and Haws. These fill in the space unoccupied by the branches of the larger trees, say the lower fifteen or twenty feet, and make an excellent thicket and wind-break. Such trees border the forest in nature and we may hope to use them with greatest success and profit. The Juniper is the only native conifer, evergreen. Probably some other introduced species may give greater satisfaction. The White Pine and the Spruce promise well. And perhaps the western pine, $P$. ponderosa, may be found useful, as its eastern range was certainly in the more recent past not far west of the Missouri and Sioux valleys.

It would be interesting to enquire how these natural groves attained their present station. Are they the remnant of a forest once continuous from the Rocky mountains to the Atlantic coast, burned out by drought and fires and so reduced 
to this sad residue? or are these groves an extension of the forests from the east, the seeds brought hither by the winds and birds? Here is a question diffieult to answer; the data obtainable not yet, perhaps, all in. Many species found around the lakes are such as to favor the latter supposition; the seeds might easily, by birds or winds, be scattered wide; but there are other species which look quite as decisively in the opposite direction. Walnuts and acorns are not by any animal save man likely to enjoy the transportation needed. The far eastern extension of some western species of trees as Pinus ponderosa at Long Pine, Neb., for instance, would seem also to look in the same direction. Prior to the advent of civilized man the forests of the continent were probably already through natural causes slowly retreating; our occupancy of the land may have only hastened nature's purpose. Here at least is a problem for our study. Hereafter, if we are to have trees and forests, we may count on having to toil for them. Eden's gate is angel-guarded.

\section{A NATURAL PARK.}

The chain of lakes we have attempted to describe, together with the groves of native oaks and elms about them, make up a natural park, taken all in all the finest in the state. There is so much native beauty as to render almost impertinent, needless, any art or artifice of man. Minnewaukon, Okoboji, had remained forever glorious. But civilized man would use the fair fields of the natural world. He throngs in thousands about each scene of natural splendor and it forthwith becomes necessary to make appointments which shall at once meet his convenience and check his vandalism. As the years go by the lakes are destined more and more to serve our Iowa people as a delightful, a convenient summer resort; to the fortunate a summer home, to toilers in shop and field a resting place where, for at least a day or two, each may forget his usual care and burden.

For this reason it seems that these groves and lakes should receive at the hands of legislators the very best attention they 
can give. The waters are already the property of the state; the shores should be as well, at least so far as is necessary to preserve intact, from injury or abuse, those portions not likely to be used by homes and villas. The scant woods by nature placed to decorate these winding, bowlder-covered banks should be religiously preserved. This will be possible only by public ownership of some intelligent sort. The state of Iowa should own these lands and provide for their proper control and management. The entire circuit of the lakes should be a highway, unimpeded, open to the world. No fences should, anywhere, come down to the water's edge, much less as now invade the lakes; nor should any obstruction or unsightly thing whatever be permitted to trespass upon a territory devoted to the instruction and peaceful enjoyment of an intelligent, orderly, happy people. Surely the time has come when our people may own and control a park by nature so fine as this, and by controlling it preserve it to the comfort and enjoyment of those who, in time, shall follow us. Naturalists will find here exceptional advantages for the prosecution of their work, and summer schools of science might flourish here as in no other quarter of the state. Let the people, not of Dickinson county only but of the northwest, once appreciate what these lakes are actually worth, and their preservation and control will no longer be a matter for argument or doubt. The lakes of Dickinson county are the opportunity of the state.

\section{WOODY PLANTS OF DICKINSON COUNTY.}

The following is a list of the woody plants of Dickinson county. In its preparation the author acknowledges the assistance of Hon. R. A. Smith, a life-long observer of the natural conditions about the lakes:

Tilia americana Linn. Linden, Bass-wood, Linn. Not uncommon between Lake Okoboji and the Gar lakes; also found along the Little Sioux river in Okoboji township. A valuable tree well worthy of cultivation; beautiful for shade and useful for lumber. 
Xanthoxylum americanum Mill. Prickly Ash. Found oceasionally around the lakes and along the Little Sioux. Valuable as an ornamental shrub only.

Acer saccharinum Wang. Hard maple, Sugar Maple. Occurs sparingly about Lake Okoboji. A tree of the highest value, but less likely to flourish in cultivation in this section of Iowa. Trees raised from the seed in groves are most promising. Nowadays called Acer saccharum Marsh by some authors.

Acer dasycarpum Ehrb. Soft maple, White Maple. Probably native. With such trees as this and the Cottonwood it is difficult to say whether they are indigenous or not. The two species are everywhere planted, and it is possible in the case of the Soft maple at least, that trees now supposed to be native are really descended from those planted by white men. A tree of the highest value in plantations, affording shelter, shade and fuel. It should, however, now be supplanted by species of more slow-growing hard-wood trees. By some authors written Acer saccharinum Linn.

Negundo aceroides Moench. Box-elder. Very common in cultivation. Probably native also about the lakes and the Little Sioux. The species also comes rapidly from the seed, but its chief value is as a nurse for other more slowly growing trees. Acer negundo Linn is the name preferred by some authors.

Rhus glabra Linn. Sumac, Smooth Sumac. Not abundant. Here and there on wooded hillsides along the lakes and the Sioux. Useful only as an ornamental shrub.

Prunus americana Willd. Wild Plum. Not uncommon about the lakes and by the banks of the Little Sioux. Valuable for fruit, valuable also as an ornamental tree and as an element of the thicket wind-break.

Prunus virginiana Linn. Choke-cherry. Apparently rare. The only specimens observed were along the Little Sioux. Probably occurs also about the lakes. Useful only as a thickettree, where its early clusters of white flowers, later shining black berries, make it very attractive. 
Prunus serotina Ehrh. Wild Cherry. Mr. Shimek reports this as occurring about the lakes, and small trees are found on the island in Grove Island marsh. A most valuable and beautiful species.

Pyrus coronaria Linn. Crab-apple. American crab. Not rare around the lakes. Tends to form a thicket, and is invaluable for this purpose, as forming an elegant and serviceable border to our forest plantations. The tree is besides one of our most beautiful ornamental trees.

Crataegus coccinea Linn. Hawthorn. Red Haw. Occurs sparingly along the Little Sioux. Mr. Shimek reports this also from the vicinity of the lakes. Very handsome, useful as an ornamental tree.

Cornus stolonifera Michx. Red Osier. Dog-wood. This handsome little shrub occurs not infrequently along the eastern shores of the Gar lakes. Probably not uncommon throughout the native groves. Flourishes in wet regions especially north and does not well bear transplanting.

Cornus paniculata L'Her. Panicled Cornel-bush. Rather rare along the lake shores. This is the most attractive of our native species, but does not flourish well on our dry uplands. The cymes of white flowers are very pretty and in fall the snow-white fruit distinguishes it.

Sambucus canadensis Linn. Elder-berry. Not common. Apparently native along the Little Sioux. Reported indigenous by the lakes, and found here and there in cultivation in gardens.

Viburnum lentago Linn. Black Haw. There are two species popularly called Black Haw, and the two forms are not always readily distinguished. The species named here is a small tree fifteen or twenty feet high, slender, with few branches; common in Minnesota and north and east. It occurs rarely in the valley of the Des Moines ten or fifteen miles east of the lakes.

Fraxinus americanus Linn. White Ash. Common everywhere, especially about Spirit lake, Hottes lake, along the Little Sioux, and everywhere planted. The species grows 
somewhat slowly as compared with eottonwood, but is twofold more valuable and makes a much handsomer grove and better wind-break. It is a matter of some surprise to find this species so common and hardy here. It is par excellence a forest tree, and shows its most perfect development in typical forest conditions much farther east. It would never be classed with the bur oak, which here it seems to rival. The fact that it is so hardy here indicates that it is just the tree for planting on these northern prairies, as the farmers fortunately need not be told. All the trees of this part of the world are more shrubby and bushy than farther east; probably because of the much harder conditions they have been called to face, especially in the matter of fire.

Ulmus americana Linn. Elm, White Elm, American Elm. Common. A most valuable tree; tough, hardy and beautiful, deserving a place in every plantation and by every roadside. Easily transplanted and easily cultivated.

Ulmus racemosa Thomas. Cork Elm, Hickory Elm. This species seems to be uncommon throughout our region. It is rather smaller and more bushy than the preceding, but the wood is finer grained, tougher and for many purposes more desirable. It may even take the place of hickory in the manufacture of tools and agricultural implements. It is, therefore, in the highest degree worthy of cultivation and preservation.

Celtis occidentalis Linn. Hackberry. Not uncommon. Said to have been in other days a very prominent forest tree, now represented by small specimens only. A fine ornamental tree, growing rapidly on prairie soils, but the wood is valuable chiefly for fuel.

Juglans nigra Linn. Black Walnut. Mr. Smith reports that black walnut trees of great size were once here at the service of the pioneer. Occasional trees are still to be seen. This is one of the most valuable of North American forest trees; easily cultivated, and the people of these counties may congratulate themselves that such a tree is here indigenous. From the seed in prairie soils it grows with great rapidity, $24 \mathrm{G}$ Rep 
but needs the protection of trees of other species. Walnuts are not easily transplanted, nor do they thrive if set singly or even in rows, that is, in one long line. The walnut is essentially a forest tree and must be bordered at least with trees of other species.

Carya amara Nutt. Bitter-nut, Pig-nut, White Hickory. Not very common. Small trees occur here and there in the lake woods, and some trees were noticed on the banks of the Little Sioux. A tree of comparatively small value, except for fuel. Like others of its family, it does not endure transplanting, but must be cultivated from the seed. The shell-bark, or white hickory proper, is not reported from these woods.

Corylus americana Walt. Hazel, Hazel-nut. Not rare along the borders of the woods and thickets; also along the Little Sioux. This species also must be cultivated from the seed.

Ostrya virginica Willd. Iron-wood, Hop-hornbeam, Leverwood. A small tree, furnishing very hard and strong wood, useful for tool handles, etc. Occurs not infrequently along the lakes and by the Little Sioux.

Quercus macrocarpa Michx. Bur Oak. Very common. By far the most common species of tree in this section of country. A few of the primeval trees of large size are still standing, near Center Lake, and on the hill enclosed by the great bend of the Little Sioux in Okoboji township. The species shows a small-fruited variety; acorns less than half an inch in diameter are the rule. This species is exceptionally hardy; groves of it occupy sometimes lonely exposed positions, where scattering small trees six to ten feet high seem to persist unchanged, growing only in slowest fashion year after year. The wood is for some purposes exceedingly valuable and good but in general is less desirable than that of the white oak which does not here occur.

Quercus mubra. Red Oak. This is the only black oak of this region; not uncommon. Trees of large size were once abundant about the southeast side of Okoboji. A very valuable lumber-tree. It is, however, like the walnut, a forest 
tree, and may be expected to grow to perfection only in a forest plantation, affording forest conditions of moisture and shade.

Salix longifolia Muhl. Long-leaved willow. Very common everywhere in the wooded district, especially around Spirit lake.

Satix amygdaloides Anders. A bushy shrub or small tree, easily distinguished by its rather large leaves, two to four inches long, white, silky beneath. Of little value save as an ornamental shrub.

Satix discolor Muhl. A small tree fifteen to thirty feet high, not rare about the marshes and lakes of Dickinson county.

Populus tremuloides Michx. Quaking asp. American aspen. Not uncommon through all the groves, especially in low grounds. The wood makes light fuel; otherwise the tree is of small value save as ornament.

Populus monilifera Aiton. Cottonwood. This tree is so commonly planted that it is by some doubted whether it be even native of either county. It seems probable, however, that the cottonwood is one of the trees indigenous to both counties. The seeds are particularly well adapted to dispersal by the wind, and young cottonwoods are almost always to be found far out on the prairies and plains. That it were not native to the two counties would be remarkable indeed. Useful chiefly because of its rapid growth; but for this very reason of the highest utility and service.

Juniperus virginiana Linn. Red Cedar. Juniper. This is the only conifer, evergreen, native to the region. A few fine old trees are yet standing near Lake Okoboji on the eastern shore. One near Fort Dodge Point is extremely old; a foot or more in thickness. This tree grows rapidly in cultivation, is remarkably handsome in its youth, but is apt to be damaged by snow as it grows older, and so loses its symmetry. It endures shade much better than most evergreens, and makes fairly good ornamental hedges and wind-breaks. 



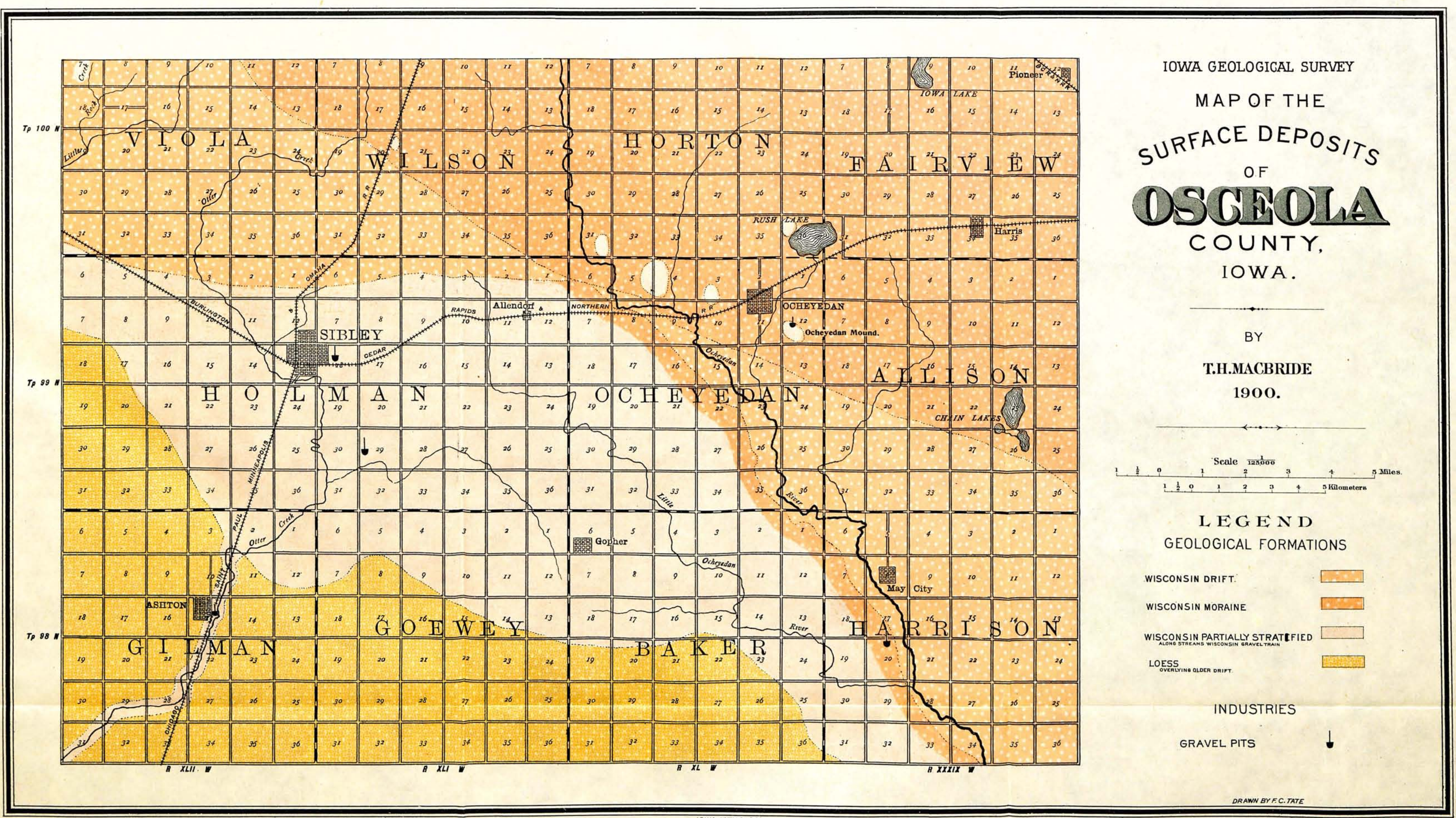

